NBER WORKING PAPER SERIES

\title{
NEGATIVE NOMINAL INTEREST RATES: THREE WAYS TO OVERCOME THE ZERO LOWER BOUND
}

\author{
Willem H. Buiter \\ Working Paper 15118 \\ http://www.nber.org/papers/w15118 \\ NATIONAL BUREAU OF ECONOMIC RESEARCH \\ 1050 Massachusetts Avenue \\ Cambridge, MA 02138 \\ June 2009
}

I would like to thank Anne Sibert, Charles Goodhart, Ben Broadbent and participants in seminars at the Center for Financial Studies at the Goethe University, Frankfurt on May 6th 2009, at the European Central Bank on May 18, 2009 and at the 13th International Conference on Macroeconomic Analysis and International Finance at the University Campus of the University of Crete in Retymno Crete, May 28-30, 2009. Comments by Fabrizio Zilibotti were especially useful in clarifying key issues involving the third method for removing the zero lower bound. The views expressed herein are those of the author(s) and do not necessarily reflect the views of the National Bureau of Economic Research.

NBER working papers are circulated for discussion and comment purposes. They have not been peerreviewed or been subject to the review by the NBER Board of Directors that accompanies official NBER publications.

(C) 2009 by Willem H. Buiter. All rights reserved. Short sections of text, not to exceed two paragraphs, may be quoted without explicit permission provided that full credit, including $\odot$ notice, is given to the source. 
Negative Nominal Interest Rates: Three ways to overcome the zero lower bound

Willem H. Buiter

NBER Working Paper No. 15118

June 2009

JEL No. E31,E4,E41,E42,E43,E44,E5,E52,E58,G01

\begin{abstract}
$\underline{\text { ABSTRACT }}$
The paper considers three methods for eliminating the zero lower bound on nominal interest rates and thus for restoring symmetry to domain over which the central bank can vary its policy rate. They are: (1) abolishing currency (which would also be a useful crime-fighting measure); (2) paying negative interest on currency by taxing currency; and (3) decoupling the numéraire from the currency/medium of exchange/means of payment and introducing an exchange rate between the numéraire and the currency which can be set to achieve a forward discount (expected depreciation) of the currency vis-a-vis the numéraire when the nominal interest rate in terms of the numéraire is set at a negative level for monetary policy purposes.
\end{abstract}

Willem H. Buiter

European Institute

London School of Economics and Political Science

Houghton Street

London WC2A 2AE

UNITED KINGDOM

and NBER

w.buiter@1se.ac.uk 


\section{Introduction}

There is a notable asymmetry in the design and implementation of monetary policy: nominal interest rates cannot be negative. During boom times, when the economy is overheating and inflation threatens to rise to undesirable levels, the central bank can raise the official policy rate (a short, risk-free nominal interest rate) to any level it deems necessary. During economic downturns, when excess capacity rises and deflation threatens, the official policy rate can be cut no further than zero. If a further stimulus is desired, unconventional monetary policy, such as quantitative easing $(\mathrm{QE})$ and credit easing $(\mathrm{CE})$ must be resorted to.

The zero lower bound is not just of academic interest. In Japan and the US, the official policy rates are effectively at their zero floors. In the UK, Bank Rate is 0.50 percent, which the Bank of England regards, for technical operational reasons, as its effective zero lower bound. In the Euro Area, the official policy rate still stands at 1.00 percent, but the rate banks get on their reserves with the central bank has been much closer to zero.

A number of economists have suggested that, using calculations based on variations of the Taylor rule (a rule that makes the official policy rate an increasing function of the output gap and of the excess of actual or expected inflation over target inflation) and ignoring the zero lower bound, the official policy rate in the US early in 2009 should have been as low as minus 5 percent or even minus 7.5 percent. ${ }^{1}$ Whatever the merits of the Taylor rule and the specific calculations, there is a strong case that the zero lower bound has indeed, during the current downturn, been a binding constraint on central bank interest rate setting.

\footnotetext{
${ }^{1}$ The minus 7.5 percent figure was suggested in March 2009 as a level of the Federal Funds target rate that could be required by the end of 2009, by Laurence Meyer, a former Fed Board member, now vice chairman of Macroeconomic Advisers, in a note to clients. The minus five percent figure was widely reported in April 2009, as the product of internal analysis prepared by Fed staff for the Federal Reserve's last policy meeting (see e.g. Financial Times (2009) and Taylor (2009b)).
} 
The zero lower bound on the short-risk-free nominal interest rate on non-monetary financial instruments derives from the existence of a risk-free nominal instrument that carries a zero interest rate. Since the instrument in question, currency, has other attractive properties that are not shared by other nominally denominated non-monetary stores of value like Treasury Bills, including legal tender status, and is, for practical purposes, perfectly liquid, a Treasury Bill with a negative nominal interest rate would be dominated by currency as a store of value. There would be a simple pure arbitrage opportunity for anyone able to borrow at a negative nominal interest rate and invest in currency.

The reason no interest, at a positive or at a negative rate, is paid on currency is that it is costly and administratively awkward and intrusive to do so. All financial instruments can be divided into two categories: bearer instruments and registered instruments. Bearer instruments have anonymous owners: the issuer (borrower) does not know the identity of the owner (holder or bearer). This makes it difficult to pay positive interest rates: the owner/bearer could present the same instrument repeatedly for interest due to the owner only once. The solution is to 'mark' the instrument itself, so it can be identified as current on interest. Historically, this was done by 'clipping coupons' of fixed interest bonds or by stamping the bond document. Paying negative interest on bearer instrument is even harder, because the issuer has to incentivise the holder to come forward to pay the issuer the interest due. The holder is anonymous. Why would he volunteer to reveal himself to the issuer?

Currency being a bearer instrument is a necessary but not a sufficient condition for the payment of interest on currency, positive or negative, to be difficult. Many of the most common bonds are, after all, bearer instruments. ${ }^{2}$ Currency, however, is a negotiable bearer

\footnotetext{
${ }^{2}$ The vast majority of international bonds, historically called Eurobonds, are bearer. Bearer bonds can take two main forms. First, the traditional definitive style, where the bonds literally are individual pieces of security printed paper in denominations of, say, $\$ 10,000$, which individual holders bring in to paying agents so as to receive payment of interest and principal. Second, global bonds, which are technically bearer instruments but
} 
bond, and one that is transferable without endorsement. A financial instrument is negotiable if it is transferable from one party to another by being delivered (with or without endorsement) so that the title passes to the transferee. ${ }^{34}$ Thus, not only does the issuer not know the identity of the holder of a negotiable bearer bond, that holder can change easily and with little cost. Negotiable bearer bonds make their owners very difficult to keep track of. The solution is that if you cannot identify the owner, you identify/mark the individual instruments themselves as current on interest.

Operationally, this marking of instruments can be achieved by putting an expiration date on the instrument. Unless interest due by the bearer to the issuer is paid before the expiration date and the instrument marked is marked as current on interest, the instrument represents no further claim on the issuer. During the 1930s, there were many experiments, in continental Europe, Canada and the US, with sub-national stamp scrip money. ${ }^{5}$ The problem

consist of a single piece of paper representing the entire issue (and so worth hundreds of millions or even billions of dollars). In practice, the terms of the global bond say that only Euroclear (the settlement system based in Brussels) or Cedelbank (the settlement system based in Luxembourg) are entitled to the proceeds of the global bond, and that Euroclear and Cedelbank will in turn divide the proceeds up amongst the end-investors whose details are stored in their electronic records. Thus the global bond is not an instrument which in practice can be passed from one owner to another, even though it is technically bearer. Effectively the bonds are dematerialised.

Bearer bonds are legal and quite common in the UK. While the bearer debenture went out of use, replaced by the non-negotiable debenture or debenture stock, transferable (in the same way as common stocks) by entry in the company's register, a number of new negotiable investment securities have evolved. They include the modern bearer bond, the negotiable certificate of deposit, and the floating rate note. A limited number of gilts have also been issued with a bearer option. Before July 1983, municipal securities in the U.S. were issued for the most part in certificate form with coupons attached. Some of these so-called old-style bearer bonds are still available in the marketplace. The issuer has no record of who owns these bonds. The owner clips the coupons and collects the interest from the issuer's paying agent. Transferring the bonds requires physical delivery and payment. Bearer bonds issued by municipal authorities were made illegal in the U.S. in 1982.

${ }^{3}$ Key elements of negotiability include the following: (1) transfer by physical delivery; (2) transfer confers on its holder unchallengeable title and (3) a negotiable instrument benefits from a number of evidential and procedural advantages in the event of a court action.

${ }^{4}$ An endorsement is a signature on a negotiable instrument indicating a person's intent to become a party to the instrument.

${ }^{5}$ From the Federal Reserve Bank of Cleveland (2008), I cite the following: "Stamp scrip, sometimes called coupon scrip, arose in several communities. It was denominated in dollars, in denominations from 25 cents to $\$ 5$, with \$1 denominations most common. Stamp scrip often became redeemable by the issuer in official U.S. dollars after one year. What made stamp scrip unique among scrip schemes was a series of boxes on the reverse side of the note. Stamp scrip took two basic forms-dated and undated (often called "transaction stamp scrip"). Typically, 52 boxes appeared on the back of dated stamp scrip, one for each week of the year. In order to spend 
in applying this to government fiat currency is that currency has no expiration date. As a financial instrument, it is like a zero coupon perpetuity or consol - promise to pay nothing forever. While private or local government IOUs may lose their value if they are not at some point redeemable into legal tender (at least in principle), currency is already legal tender. It is also irredeemable: it does not represent a claim on the issuer for anything other than the same amount of itself. So incentives have to be created to induce private holders of currency to reveal their ownership of currency, come forward and pay any negative interest due. No government has, as yet, had the stomach for that.

Registered instruments are instruments where the identity of the owner is recorded in some central register. Common stock is an example. So are bank accounts, including commercial bank accounts held with the central bank. Negative interest rates on bank balances would be as easily implemented as positive interest rates - both are just entries in an electronic ledger. Negative dividends are not technically difficult (it would amount to a compulsory cash call on the shareholders) although it may not be legally permissible in most jurisdictions. In addition, since equity has a variable market value, nominal rates of return can be negative, when dividends and capital gains are considered together. The same holds for fixed-interest nominal debt instruments.

This paper considers three methods for removing the zero lower bound on nominal interest rates. Each follows a quite different route, although the end result is the same. The first, abolishing currency, ensures that all money (means of payment/media of exchange) consists of registered instruments on which the payment of positive or negative interest is trivially easy. The second, taxing currency, is a means of paying negative interest on

the dated scrip, the stamps on the back had to be current. Each week, a two-cent stamp needed to be purchased from the issuer and affixed over the corresponding week's box on the back of the scrip. Over the coming week, the scrip could be spent freely within the community. Whoever was caught holding the scrip at week's end was required to attach a new stamp before spending the scrip. In this scheme, money became a hot potato, with individuals passing it quickly to avoid having to pay for the next stamp." 
currency, using what amounts to stamp scrip methods, even though more high-tech ways than physically stamping bank notes are now available as means of identifying currency notes as current on interest due. The third method decouples the numéraire function of currency from its means of payment/medium of exchange function and introduces a variable exchange rate between a unit of the one-period safe non-monetary security denominated in terms of the numéraire and the currency/means of payment. That exchange rate can either be set by the government or be market-determined. This permits the nominal interest rate in terms of the numéraire to be negative, even though the nominal interest rate in terms of the currency is subject to the zero lower bound.

The literature on negative nominal interest rates is limited. There is the notable work by Silvio Gesell (1916) and the Great Depression-era writings of Robert Eisler (1932) and Irving Fisher (1933). In the 'modern era', only Robert Hall has repeatedly addressed issues close to the ones considered in this paper (Hall (1983, 1997, 2002), Hall and Woodward (2009)). The issue of the zero lower bound became of interest again since about 1996, following the Japanese zero interest rate policy and experiment with quantitative easing, and because of the low nominal interest rates encountered in much of Europe and the US following the bursting of the tech bubble at the end of 2000. Examples are Goodfriend (2000), Buiter and Panigirtzoglou (2001, 2003), Buiter (2004, 2007a), Buiter and Sibert (2007), Davies (2004) and Fukao (2005). The experience of having both the Fed and the Bank of Japan effectively at the zero lower bound, the Bank of England very close to it and the ECB also not far away, resurrected the policy debate, mainly in the blogosphere, in parliamentary or congressional evidence or in speeches since 2008 (Mankiw (2009), Buiter, (2009a, b, c), Taylor (2009a,b)).

Section 1 establishes a map between the two short nominal interest rates of the formal model and the much larger set of short nominal interest rates encountered in the real world of 
central banking. Section two develops a simple formal model which is used, in Section 3, to present the three methods for removing the zero lower bound. Section 4, prompted by discussions with Fabrizio Zilibotti, offers a number of reinterpretations and extensions of the third method - unbundling numéraire and currency. Section 5 points out that the model does not support a liquidity trap equilibrium (short nominal interest rates at their lower bounds for all maturities) if the authorities pursue even the mildest form of quantitative easing.

\section{Clearing the ground for the formal model}

The academic version of the zero lower bound problem is generally stated in terms of a non-negativity constraint on 'the' short nominal risk-free rate of interest - the one-period rate in a discrete time model and the instantaneous rate of interest in a continuous time model. In the world of actual monetary policy making, there are many different short-term nominal rates. In what follows I define the more important ones, relate them to each other and make explicit the assumptions that permit one to simplify the exposition to the point that it is meaningful to speak of the short nominal interest rate.

We start with the following set of six one-period nominal interest rates:

$i$ : interest rate on one - period Treasury Bills.

$i^{M}$ : interest rate on base money held for one period.

$i^{N}$ : interest rate on currency (notes and coins) held for one period.

$i^{D}:$ one-period interest rate on bank reserves (deposits) held with the central bank.

$i^{B}$ : one-period interest rate on collateralised commercial bank borrowing from the central bank. $i^{C B}$ : one-period official policy rate.

In addition to $i^{B}$, which measures the one-period interest rate at which commercial banks can borrow from the central bank against high-grade collateral, generally through repos, most central banks have a discount window where banks can borrow against a wider range of collateral, sometimes including illiquid assets. For reasons of space this is not 
considered here. Nor are the many ad-hoc facilities created by central banks during the current crisis.

The first five of these interest rates are attached to financial instruments that may have a non-negative carry cost - the cost of storing, safekeeping (including insurance) and using these securities.

$k$ : carry cost on one-period Treasury Bills.

$k^{M}$ : one-period carry cost on base money.

$k^{N}$ : one-period carry cost on currency.

$k^{D}$ : one-period carry cost on bank reserves with the central bank.

$k^{B}$ : one-period carry cost on collateralised bank borrowing from the central bank.

The interest-rate on one-period Treasury Bills will in what follows stand for the safe, that is, free of default risk, nominal yield on non-monetary assets. Because even US sovereign debt is no longer viewed by the markets as entirely free of default risk (credit default swaps written on five-year US sovereign debt have during 2008 shown a default risk premium of around 40 basis points), there may be no completely default-risk free assets in the real world. ${ }^{6}$ Base money, $M$, has two components: currency, $N$, (bank notes and coin in circulation with the public) and reserves held by commercial banks with the central bank, $D$. For simplicity, I do not distinguish here between required reserves and excess reserves or other partitions of total reserves. Unsecured or non-collateralised bank borrowing from the central bank is not risk free, because banks can default on their obligations. Commercial banks therefore typically borrow from the central banks against collateral. When the quality of the collateral is very high (if, say, Treasury bills or bonds are offered as collateral or are used in repo (sale and repurchase) contracts between the commercial bank and the central

\footnotetext{
${ }^{6}$ Which counterparty would pay out on a CDS written on US Treasury debt is not entirely clear, of course. This part of the CDS market is rather unusual.
} 
bank), the loan from the central bank has the risk of the sovereign and is therefore, for the purposes of this paper, risk-free.

Finally there is the official policy rate of the central bank. In the US, this is the Federal Funds target rate, which is not a rate charged or paid on any instrument, but instead a guide or target for the overnight rate in the Federal Funds market (a market for unsecured interbank borrowing and lending of excess reserves with the Fed). In the UK it is Bank Rate, the overnight interest rate paid on commercial bank reserves with the Bank of England. From 1997 until early 2006, however, the official policy rate in the UK was the two-week repo rate, the rate at which the Bank of England would lend for a two-week maturity to commercial banks against eligible, high grade collateral. In the Euro Area the official policy rate is, since July 2008, the Main refinancing operations fixed rate (for fixed rate tenders). This is a repo rate against (supposedly) high-grade collateral for a range of maturities from overnight to a year. Before July 2008, it was the Main refinancing operations Variable rate tenders Minimum bid rate. In Japan, the official policy rate is a target rate for the Uncollateralized Overnight Call Rate, the lending rate charged for uncollateralised loans in the Japanese interbank market, the Japanese version of the Federal Funds rate. In Switzerland, the official policy rate is a target (range) for 3-month Libor, the 3-month unsecured interbank borrowing rate. The variety of arrangements in the real world is quite remarkable.

The following restrictions on the relative magnitudes of these short rates and their associated carry costs are plausible:

$$
\begin{aligned}
& i-k \geq i^{M}-k^{M} \\
& \text { or, in terms of the two components of base money: } \\
& i-k \geq i^{N}-k^{N} \\
& i-k \geq i^{D}-k^{D} \\
& i^{B}-k^{B} \geq i^{D}-k^{D}
\end{aligned}
$$


The restriction that the risk-free one-period interest rate on non-monetary assets (net of carry costs) cannot be below the rate on base money (net of carry costs) or below the rate on the components of base money follows from the assumption that base money (currency and reserves) yields non-pecuniary liquidity services that are not found to the same extent in other assets. The restriction that the interest rate at which banks borrow against collateral from the central bank is not below the rate the banks earn when depositing funds with the central bank (both net of carry costs) is an assumption about central bank behaviour: even with sovereign debt instruments as collateral, a central bank loan to a private bank cannot have a lower default risk than a private bank's deposit with the central bank. The central bank does not wish to offer the commercial banks a pure arbitrage opportunity. This is reflected in the rates the central bank sets for its deposits and loans.

The only financial instrument of the five considered likely to have significant carry costs is currency: it is bulky and costly to store, it can be stolen and it can be destroyed by fires and other man-made or natural disasters. I therefore assume

$$
\begin{aligned}
& k^{N}>0 \\
& k=k^{D}=k^{B}=0
\end{aligned}
$$

Finally, I assume

$$
i^{D} \leq i^{C B} \approx i \leq i^{B}
$$

It therefore follows that

$$
i \geq i^{N}-k^{N}
$$

Even if the interest rate on currency is zero, $i^{N}=0$, the short nominal interest rate on non-monetary securities could be some (small) negative number, because of the high carry costs on currency. In the formal model of the next section, I will simplify notation by equating all risk-free non-monetary one-period interest rates to each other, and by setting the carry costs on currency equal to zero, $k^{N}=0$. This gives us: 


$$
i=i^{C B}=i^{D}=i^{B} \geq i^{N}
$$

\section{A simple model of the euro currency economy}

I will formally present the main ideas about removing the lower bound on the shortterm risk-free nominal interest rate using a simple model of a closed endowment economy with a representative infinite-lived household-worker-portfolio manager and a government sector consisting of a consolidated Central Bank and Treasury. For simplicity, and because none-of the results depend on it, I assume that there exists a complete set of time and statecontingent markets. Price setting follows a variant of the New-Keynesian Calvo-Woodford approach (Calvo (1983), Woodford (2003)).

\subsection{The private sector in the euro-currency economy}

The competitive representative household receives an endowment $y_{t}>0$ of a single perishable commodity (potential labour time) each period, $t=0,1,2, \ldots$, which it takes as given. It can either consume the endowment or sell it to other consumers or to the government. The household maximizes lifetime expected utility, as defined in equation (3).

The lifetime utility functional is defined over an infinite horizon, is time-additive and has a constant psychological discount factor $\beta$. The period utility function is increasing in consumption $c_{t} \geq 0$ and real base money balances $m_{t} \geq 0$, and strictly concave. The results of the paper are not affected if the 'money-in-the-direct-utility-function approach' were to be replaced by a 'cash-in-advance' approach, a 'shopping-time' approach or a 'money-in-theproduction-function' approach.

For expositional and notational simplicity, the period utility function is assumed to be additively separable in consumption, leisure and the real euro monetary base. Each of the sub-utility functions is assumed to be iso-elastic. The conditional expectation operator at 
time $t$ is denoted $E_{t}$, the nominal stock of base money at the end of period $t$ is $M_{t}, P_{t}$ is the period- $t$ general price level and $m_{t} \equiv \frac{M_{t}}{P_{t}}$. Note that $M_{t}$ is the stock of euro base money and that $P_{t}$ is the euro price level in period $t$. Most of the time, the formal model treats base money as a homogeneous instrument with an exogenous single-period own rate of interest, $i^{M}$, rather than decomposing it into currency, $N$, and reserves with the central bank, $D$, each with its own, possibly distinct, interest rate. Where it matters for the analysis, this simplification is relaxed.

$$
\begin{aligned}
U_{0} & =E_{0} \sum_{t=0}^{\infty} \beta^{t}\left[\frac{1}{1-\gamma} c_{t}^{1-\gamma}+\eta \frac{1}{1-\gamma} \ln m_{t}^{1-\gamma}\right] \\
0 & <\beta<1 ; \eta, \gamma>0
\end{aligned}
$$

The household's optimisation programme is subject to its period budget identity (4), its solvency constraint (5) and initial conditions for its financial assets (6). The risk-free oneperiod nominal interest rate on non-monetary assets in period $t$ is $i_{t+1, t}$, the period $t$ one-period risk-free nominal interest rate on base money is $i_{t+1, t}^{M}, \tau_{t}$ is real lump-sum taxes paid in period $t, I_{t+1, t}$ is the one-period stochastic nominal discount factor in period $t, W_{t}$ is the value of the portfolio of financial assets (including money) in period $t$, and $A_{t}$ is the value in period $t$ of the portfolio of non-monetary financial assets carried over from period $t-1$, including interest or other income paid.

$$
\begin{gathered}
E_{t}\left(I_{t+1, t} W_{t+1}\right) \equiv W_{t}+P_{t}\left(y_{t}-c_{t}-\tau_{t}\right)-\left(\frac{i_{t+1, t}-i_{t+1, t}^{M}}{1+i_{t+1, t}}\right) M_{t} \\
\lim _{k \rightarrow \infty} E_{t} I_{k+1, t} W_{k} \geq 0 . \\
M_{-1}=\bar{M}_{-1}>0 \\
A_{0}=\bar{A}_{0}
\end{gathered}
$$


In general, $I_{t_{1}, t_{0}}$ is the nominal stochastic discount factor between periods $t_{1}$ and $t_{0}$. It has the following properties:

$$
\begin{array}{rlrl}
I_{t_{1}, t_{0}} & \equiv \prod_{k=t_{0}+1}^{t_{1}} I_{k, k-1} ; & & t_{1}>t_{0} \\
& \equiv 1 & t_{1}=t_{0} .
\end{array}
$$

The risk-free one-period nominal rate of interest is defined by the following relationship:

$$
\frac{1}{1+i_{t+1, t}}=E_{t} I_{t+1, t}
$$

By definition:

$$
W_{t} \equiv A_{t}+\left(1+i_{t, t-1}^{M}\right) M_{t-1}
$$

The period budget identity and the solvency constraint imply the household's intertemporal budget constraint:

$$
\begin{aligned}
W_{t} & =P_{t}\left(c_{t}+\tau_{t}-y_{t}\right)+\left(\frac{i_{t+1, t}-i_{t+1, t}^{M}}{1+i_{t+1, t}}\right) M_{t} \\
& +E_{t} \sum_{j=1}^{\infty} I_{t+j, t}\left(P_{t+j}\left(c_{t+j}+\tau_{t+j}-y_{t+j}\right)+\left(\frac{i_{t+j+1, t+j}-i_{t+j+1, t+j}^{M}}{1+i_{t+j+1, t+j}}\right) M_{t+j}\right) \\
& +E_{t} \lim _{T \rightarrow \infty} I_{t+T, t} W_{t+T}
\end{aligned}
$$

The inflation factor ( 1 plus the proportional rate of inflation) between periods $t_{1}$ and $t_{0}$ is denoted $\Pi_{t_{1}, t_{0}} \equiv P_{t_{1}} / P_{t_{0}}$ and the real stochastic discount factor between periods $t_{1}$ and $t_{0}$ by $R_{t_{1}, t_{0}} \equiv I_{t_{1}, t_{0}} \Pi_{t_{1}, t_{0}}$. The one-period risk-free real interest rate, $r_{t+1, t}$ is defined as:

$$
\frac{1}{1+r_{t+1, t}} \equiv E_{t} R_{t+1, t}
$$

For future reference, the multi-period stochastic discount factors are defined recursively as follows: 


$$
\begin{array}{rlrl}
R_{t_{1}, t_{0}} & \equiv \prod_{k=t_{0}+1}^{t_{1}} R_{k, k-1} ; & & t_{1}>t_{0} \\
& \equiv 1 & t_{1}=t_{0} .
\end{array}
$$

The optimality conditions of the household optimisation programme are the following $\left(\operatorname{Cov}_{t}\right.$ denotes the conditional covariance at time $\left.t\right)$ :

$$
\begin{aligned}
& c_{t}^{-\gamma}=\beta\left(1+r_{t+1, t}\right) E_{t} c_{t+1}^{-\gamma} \\
& \frac{M_{t}}{P_{t}}=\left[\eta\left(\frac{1+i_{t+1, t}}{i_{t+1, t}-i_{t+1, t}^{M}}\right)\right]^{1 / \gamma} c_{t} \\
& \lim _{T \rightarrow \infty} E_{t}\left(\frac{\beta^{T}}{c_{t+T}^{\gamma}} \frac{M_{t+T}}{P_{t+T}}\right)=0 \\
& 1+r_{t+1, t}=\left(1+i_{t+1, t}\right)\left(E_{t} \Pi_{t+1, t}^{-1}+\frac{\operatorname{Cov}_{t}\left(\Pi_{t+1, t}^{-1}, c_{t+1}^{-\gamma}\right)}{E_{t} c_{t+1}^{-\gamma}}\right) \\
& W_{t}=P_{t}\left(c_{t}+\tau_{t}-y_{t}\right)+\left(\frac{i_{t+1, t}-i_{t+1, t}^{M}}{1+i_{t+1, t}}\right) M_{t} \\
& +E_{t} \sum_{j=1}^{\infty} I_{t+j, t}\left(P_{t+j}\left(c_{t+j}+\tau_{t+j}-y_{t+j}\right)+\left(\frac{i_{t+j+1, t+j}-i_{t+j+1, t+j}^{M}}{1+i_{t+j+1, t+j}}\right) M_{t+j}\right) \\
& \text { or equivalently } \\
& E_{t} \lim _{T \rightarrow \infty} I_{t+T, t} W_{t+T}=0
\end{aligned}
$$

The household solvency constraint (5) holds with equality. Equation (13) is the Euler equation for consumption. The demand for real euro money balances is proportional to consumption and depends inversely on the pecuniary opportunity cost of holding money, $i_{t+1, t}-i_{t+1, t}^{M}$. Equation (14) is the transversality condition governing the long-run behaviour of the stock of money balances (see Buiter and Sibert (2007)). It says that the value, across all states of nature, of the terminal stock of real money balances, evaluated at its appropriate present value shadow price, is zero. So either the stock of real money balances goes to zero or its shadow price goes to zero, or both. The state-contingent present value shadow price of 
terminal real money balances equals the terminal marginal utility of consumption discounted using the subjective discount factor. The risk-free real interest rate equals the risk-free nominal interest rate minus the expected inflation rate and the inflation risk premium (equation (16)).

Pricing behaviour is assumed to be governed by a New-Keynesian Phillips curve with both a back-ward looking and forward-looking inflation component in the augmentation term'; $\bar{y}_{t}>0$ is the exogenous level of capacity output or potential output in period $t$.

$$
\begin{gathered}
\Pi_{t, t-1}=\alpha^{-1}\left(y_{t}-\bar{y}_{t}\right)+(1-\lambda) E_{t} \Pi_{t+1, t}+\lambda \Pi_{t-1, t-2} \\
1 \geq \lambda \geq 0 ; \alpha \geq 0 \\
P_{-1}=\bar{P}_{-1} \\
\pi_{-1,-2}=\bar{\pi}_{-1,-2}
\end{gathered}
$$

Perfect price flexibility is the special case of (18) where $\alpha=0$, in which case it becomes $y_{t}=\bar{y}_{t}$ for all $t \geq 0$.

\subsection{The government in the euro currency economy}

The government in what follows is the consolidated general government and central bank. It spends on real goods and services, $g_{t}$ with $0 \leq g_{t} \leq \bar{y}_{t}$, raises real revenues $\tau_{t}$ and finances its financial deficit by issuing base euro money, $M_{t}$ or safe, euro-denominated oneperiod government debt, $B_{t}$. The government's period budget identity is

$$
M_{t}+B_{t} \equiv\left(1+i_{t, t-1}^{M}\right) M_{t-1}+\left(1+i_{t, t-1}\right) B_{t-1}+P_{t}\left(g_{t}-\tau_{t}\right)
$$

This can be re-written as

$$
\left(1+i_{t, t-1}^{M}\right) M_{t-1}+\left(1+i_{t, t-1}\right) B_{t-1} \equiv P_{t}\left(\tau_{t}-g_{t}\right)+\left(\frac{i_{t+1, t}-i_{t+1, t}^{M}}{1+i_{t+1, t}}\right) M_{t}+E_{t} I_{t+1, t}\left(\left(1+i_{t+1, t}^{M}\right) M_{t}+\left(1+i_{t+1, t}\right) B_{t}\right)
$$

Solving this forward recursively yields: 


$$
\begin{aligned}
\left(1+i_{t, t-1}^{M}\right) M_{t-1}+\left(1+i_{t, t-1}\right) B_{t-1} \equiv & P_{t}\left(\tau_{t}-g_{t}\right)+\left(\frac{i_{t+1, t}-i_{t+1, t}^{M}}{1+i_{t+1, t}}\right) M_{t} \\
& +E_{t} \sum_{j=1}^{\infty} I_{t+j, t}\left(P_{t+j}\left(\tau_{t+j}-g_{t+j}\right)+\left(\frac{i_{t+j+1, t+j}-i_{t+j+1, t+j}^{M}}{1+i_{t+j+1, t+j}}\right) M_{t+j}\right) \\
& +E_{t} \lim _{T \rightarrow \infty} I_{t+T+1, t}\left(\left(1+i_{t+T+1, t+T}^{M}\right) M_{t+T}+\left(1+i_{t+T+1, t+T}\right) B_{t+T}\right) \\
& \text { or, equivalently } \\
\left(1+i_{t, t-1}\right) B_{t-1} \equiv & P_{t}\left(\tau_{t}-g_{t}\right)+M_{t}-\left(1+i_{t, t-1}^{M}\right) M_{t-1} \\
& +E_{t} \sum_{j=1}^{\infty} I_{t+j, t}\left(P_{t+j}\left(\tau_{t+j}-g_{t+j}\right)+M_{t+j}-\left(1+i_{t+j, t+j-1}^{M}\right) M_{t+j-1}\right) \\
& +E_{t} \lim _{T \rightarrow \infty} I_{t+T+1, t}\left(1+i_{t+T+1, t+T}\right) B_{t+T}
\end{aligned}
$$

The equivalence of the two intertemporal government budget identities in (21) can also be expressed through what I have called the intertemporal seigniorage identity, linking two common concepts of 'seigniorage' - the revenue obtained by the state from the issuance of base money (Buiter (2007b)). The first is the present discounted value of current and future base money issuance; the second is the present discounted value of current and future interest payments foregone due to the state's issuance of base money rather than risk-free non-monetary assets:

$$
\begin{aligned}
E_{t} \sum_{j=1}^{\infty} I_{t+j, t}\left(M_{t+j}-\left(1+i_{t+j, t+j-1}^{M}\right) M_{t+j-1}\right) & \equiv E_{t} \sum_{j=0}^{\infty} I_{t+j, t}\left(\frac{i_{t+j+1, t+j}-i_{t+j+1, t+j}^{M}}{1+i_{t+j+1, t+j}}\right) M_{t+j} \\
& E_{t} \lim _{T \rightarrow \infty} I_{t+T+1, t}\left(1+i_{t+T+1, t+T}^{M}\right) M_{t+T} \\
& -\left(1+i_{t, t-1}^{M}\right) M_{t-1}
\end{aligned}
$$

The solvency constraint for the government is that the present discounted value of its terminal non-monetary liabilities be non-positive:

$$
E_{t} \lim _{T \rightarrow \infty} I_{t+T+1, t}\left(1+i_{t+T+1, t+T}\right) B_{t+T} \leq 0
$$

Note the contrast between (23) and (5). Anticipating the asset market equilibrium condition, it is clear that, in equilibrium,

$$
A_{t}=\left(1+i_{t, t-1}\right) B_{t-1}
$$


Since $W_{t}=A_{t}+\left(1+i_{t, t-1}^{M}\right) M_{t-1}=\left(1+i_{t, t-1}\right) B_{t-1}+\left(1+i_{t, t-1}^{M}\right) M_{t-1}$, the household solvency constraint (5) can be written as:

$$
E_{t} \lim _{T \rightarrow \infty} I_{t+T+1, t}\left(\left(1+i_{t+T+1, t+T}\right) B_{t+T}+\left(1+i_{t+T+1, t+T}^{M}\right) M_{t+T}\right) \geq 0
$$

Comparing (23) and (24), households treat their holdings of government base money as an asset, even in the long run, while the government recognises that fiat base money is irredeemable: it does not represent a claim on the issuer for anything other than the same amount of itself (two five euro notes for one ten euro note). As it is irredeemable it does not belong in the government's solvency constraint. This, I believe, is the correct mathematical expression of the well-know proposition in monetary economics that fiat money represents an asset to the owner, but not a liability to the issuer (see Buiter (2003)).

Government spending, $g_{t}$, is exogenous, as is the nominal interest rate on euro base money, $i_{t, t-1}^{M}$. The short risk-free nominal interest rate on the euro-denominated bond is governed by a simplified Taylor rule, where the short rate responds more than one-for-one to the expected rate of inflation, as long as the lower bound constraint, that the short risk-free nominal interest rate on bonds cannot be lower than the short risk-free nominal interest rate on base money, is not binding. If the Taylor rule were to cause the constraint to bind, the short nominal interest rate on bonds is set equal to the nominal interest rate on base money; $\hat{\Pi}-1$ is the exogenous target inflation rate.

$$
\begin{gathered}
1+i_{t+1, t}=\beta^{-1} \hat{\pi}+\phi\left(E_{t} \Pi_{t+1, t}-\hat{\Pi}\right), \text { if } \beta^{-1} \hat{\Pi}+\phi\left(E_{t} \Pi_{t+1, t}-\hat{\Pi}\right)>1+i_{t+1, t}^{M} \\
=1+i_{t+1, t}^{M} \text { if } \beta^{-1} \hat{\Pi}+\phi\left(E_{t} \Pi_{t+1, t}-\hat{\Pi}\right) \leq 1+i_{t+1, t}^{M} \\
\phi>1
\end{gathered}
$$

If the lower bound constraint binds, the government engages in quantitative easing, according to

$$
\text { If } i_{t+1, t}=i_{t+1, t}^{M} \text { then } M_{t+1}=\left(1+\mu_{t+1, t}\right) M_{t}
$$


The proportional growth rate of base money under quantitative easing, $\mu_{t+1, t}$, is assumed to be exogenous subject to $\mu_{t+1, t}>-1$. When the lower bound constraint $i \geq i^{M}$ binds, the nominal stock of money becomes a choice variable of the government, or policy instrument. This is true even when the authorities 'monetary' policy rule when the lower bound constraint does not bind, is a rule for the short nominal interest rate, like the simplified Taylor rule of this model. The policy rule governing the nominal stock of base money under quantitative easing could take any form. The exogenous sequence of base money growth rates assumed here is just for expositional simplicity. The second half of the interest rate rule in $(25)$,

$$
1+i_{t+1}=1+i_{t+1, t}^{M} \text { if } \beta^{-1} \hat{\Pi}+\phi\left(E_{t} \Pi_{t+1, t}-\hat{\Pi}\right) \leq 1+i_{t+1, t}^{M}
$$

is not redundant. In principle, should the Taylor rule produce a nominal interest rate value at or below the interest rate on money, the authorities could set the actual interest rate at any level equal to or greater than the interest rate on money.

When the lower bound constraint does not bind, the nominal stock of base money, $M_{t}$, is endogenously determined from the money demand function (14). The stock of oneperiod non-monetary government debt, $B_{t}$, and real lump-sum taxes, $\tau_{t}$, are only constrained by the requirement that the government's solvency constraint (23) be satisfied. There are many possible tax rules or borrowing rules satisfying this, including, trivially, the rule that the stock of non-monetary public debt is always equal to zero:

$$
\tau_{t}=g_{t}-\frac{1}{P_{t}}\left(M_{t}-\left(1+i_{t, t-1}^{M}\right) M_{t-1}-\left(1+i_{t, t-1}\right) B_{t-1}\right) \quad t \geq 0
$$

\subsection{Equilibrium in the euro currency economy}

Goods market equilibrium and asset market equilibrium are given by (27) and (28) respectively, for $t \geq 0$. 


$$
\begin{gathered}
y_{t}=c_{t}+g_{t} \\
A_{t}=\left(1+i_{t, t-1}\right) B_{t-1}
\end{gathered}
$$

The full set of equilibrium conditions consists of equations (29) to (35) for $t \geq 0$, the transversality condition (36) and the initial conditions (37) and (38). They determine, for $t \geq 0$, and for given state-contingent sequences of $\left\{g_{t}, i_{t, t-1}^{M}, \mu_{t, t-1}, \bar{y}_{t}\right\}$ the equilibrium values of $\left\{c_{t}, r_{t+1, t}, i_{t+1, t}, M_{t}, P_{t}, \Pi_{t, t-1}\right\}$

$$
\begin{aligned}
& c_{t}^{-\gamma}=\beta\left(1+r_{t+1, t}\right) E_{t} c_{t+1}^{-\gamma} \\
& \frac{M_{t}}{P_{t}}=\left[\eta\left(\frac{1+i_{t+1, t}}{i_{t+1, t}-i_{t+1, t}^{M}}\right)\right]^{1 / \gamma} c_{t} . \\
& 1+r_{t+1, t}=\left(1+i_{t+1, t}\right)\left(E_{t} \Pi_{t+1, t}^{-1}+\frac{\operatorname{Cov}_{t}\left(\Pi_{t+1, t}^{-1}, c_{t+1}^{-\gamma}\right)}{E_{t} c_{t+1}^{-\gamma}}\right) \\
& \Pi_{t, t-1}=\alpha^{-1}\left(c_{t}+g_{t}-\bar{y}_{t}\right)+(1-\lambda) E_{t} \Pi_{t+1, t}+\lambda \Pi_{t-1, t-2} \\
& 1+i_{t+1, t}=\beta^{-1} \hat{\Pi}+\phi\left(E_{t} \Pi_{t+1, t}-\hat{\Pi}\right) \text {, if } \beta^{-1} \hat{\Pi}+\phi\left(E_{t} \Pi_{t+1, t}-\hat{\Pi}\right)>1+i_{t+1, t}^{M} \\
& =1+i_{t+1, t}^{M} \text { if } \beta^{-1} \hat{\Pi}+\phi\left(E_{t} \Pi_{t+1, t}-\hat{\Pi}\right) \leq 1+i_{t+1, t}^{M} \\
& \text { If } i_{t+1, t}=i_{t+1, t}^{M} \text { then } M_{t+1}=\left(1+\mu_{t+1, t}\right) M_{t} \\
& \Pi_{t+1, t} \equiv \frac{P_{t+1}}{P_{t}} \\
& \lim _{T \rightarrow \infty} E_{0}\left(\frac{\beta^{T}}{c_{T}^{\gamma}} \frac{M_{T}}{P_{T}}\right)=0 \\
& M_{-1}=\bar{M}_{-1}>0 \\
& P_{-1}=\bar{P}_{-1} \\
& \Pi_{-1,-2}=\bar{\Pi}_{-1,-2}
\end{aligned}
$$

\subsection{The deterministic steady state in the euro currency economy}


It will be useful for future reference, to consider the steady state of the deterministic special case of the model when all exogenous variables are constant. This is also the stationary (fundamental) equilibrium of the flexible price level version $\left(\alpha^{-1}=0\right)$ of the model.

$$
\begin{gathered}
1+r=\beta^{-1} \\
m \equiv \frac{M_{t}}{P_{t}}=\left[\eta\left(\frac{1+i}{i-i^{M}}\right)\right]^{1 / \gamma}(\bar{y}-g) \\
\Pi=\frac{1+i}{1+r} \\
\lim _{T \rightarrow \infty} \frac{\beta^{T}(\bar{y}-g)^{\gamma}}{M_{T}}=\lim _{T \rightarrow \infty}\left(\frac{\beta^{T}}{(\bar{y}-g)^{\gamma}} \frac{M_{0}(1+\mu)^{T}}{\Pi^{T} P_{0}}\right)=\lim _{T \rightarrow \infty}\left((\bar{y}-g)^{-\gamma} \frac{M_{0}}{P_{0}}\left(\frac{1+\mu}{1+i}\right)^{T}\right) \\
\text { If } \beta^{-1}>1+i^{M} \text { then } 1+i=\beta^{-1} \hat{\pi} \\
\text { If } \beta^{-1} \hat{\Pi} \leq 1+i^{M} \text { then } i=i^{M} \\
\text { If } i=i^{M} \text { then } M_{t+1}=(1+\mu) M_{t}
\end{gathered}
$$

\subsection{The lower bound can become a binding constraint in the euro currency economy}

It is clear that the constraint $i \geq i^{M}$ can become binding in our model. From equations (39) to (44), interpreted as the fundamental solution of the deterministic flexible price level special case when the exogenous variables are all constant, a sufficiently low target rate of inflation, $\hat{\Pi}-1$, possibly assisted by a sufficiently low pure rate of time preference, $\beta^{-1}-1$, can cause the lower bound constraint to bind. From equation (43), however, this would require a negative target rate of inflation that is equal to or larger in absolute value than the pure rate of time preference, if the nominal interest rate on base money is zero. In the New- 
Keynesian variant of the model $(\alpha>0)$, there always exists a sufficiently large negative shock to $g_{t}-\bar{y}_{t}$ to ensure that the lower bound constraint binds.

\section{Overcoming the lower bound on nominal interest rates}

I now consider the three methods for removing the lower bound on nominal interest rates referred to in the introduction: (1) abolishing currency, (2) paying negative interest on currency or taxing currency, and (3) separating the medium of exchange/means of payment function from the numéraire function.

\subsection{Abolishing currency}

Base money, $M$, is the sum of currency, $N \geq 0$ and bank deposits held with the central bank, $D .^{7}$ The interest rate on currency, $i^{N}$, is zero, because it is a negotiable bearer bond. The interest rate on commercial bank deposits with the central bank, $i^{D}$ can be zero, positive or negative without significant administrative or enforcement costs, because they are registered financial instruments. From a government and private sector financing perspective, $M \equiv N+D$, but from the point of view of the provision of liquidity services, currency and deposits may not be perfect substitutes. ${ }^{8}$ One can formalise this by representing base money in the utility function as a constant-returns-to-scale CES function of $N$ and $D$, with elasticity of substitution $\theta$ between currency and bank deposits as regards the provision

\footnotetext{
${ }^{7}$ Without changing the argument in any meaningful way, we can permit negative values for $D$, letting that stand for commercial bank borrowing from the central bank against high-grade collateral, say Treasury Bills.

8 The government's period budget identity (20), for instance, becomes

$N_{t}+D_{t}+B_{t} \equiv N_{t-1}+\left(1+i_{t, t-1}^{D}\right) D_{t-1}+\left(1+i_{t, t-1}\right) B_{t-1}+P_{t}\left(g_{t}-\tau_{t}\right)>$
} 
of liquidity services. So $m$ in the period utility function in equation (3) is no longer given by $m \equiv \frac{M}{P}$ but becomes:

$$
\begin{gathered}
m=P^{-1} \Lambda\left(a N^{\frac{\theta-1}{\theta}}+(1-a) D^{\frac{\theta-1}{\theta}}\right)^{\frac{\theta}{\theta-1}} \\
\Lambda>0 ; 0 \leq a \leq 1, \theta \geq 0
\end{gathered}
$$

Abolishing currency would mean setting $N_{t}=0, t \geq 0$, leaving only bank deposits with the central bank to provide the monetary base function. With positive or negative interest rates on bank deposits with the central bank feasible at trivial cost, the lower bound on the short, risk-free non-monetary nominal interest rate would be removed.

The expected welfare gain associated with the removal of the zero lower bound on currency would have to be balanced against the welfare consequences of the loss of currency. In our model, there would be no welfare impact from the loss of currency if currency and bank deposits were perfect substitutes as regards the provision of liquidity services $(\theta=+\infty)$. Even if currency and commercial bank deposits with the central bank are imperfect substitutes as regards the provision of liquidity services, the authorities can still achieve satiation with real liquidity services, even without currency, by setting $i_{t+1, t}^{M}=i_{t+1, t}^{D}=i_{t+1, t}$, that is, by the interest rate on commercial bank reserves with the central bank tracking the short safe nominal rate on non-monetary securities.

What would the costs of abolishing currency (that is, government-issued fiat base money in the form of negotiable and freely transferable bearer securities)?

In advanced industrial countries, with well-developed financial markets and institutions, and with an ever-growing range of electronic payment and settlement vehicles, currency has effectively become a redundant medium of exchange and means of payment for legitimate, legal transactions (see e.g. Bolt (2003)). As regards legitimate transactions, they 
are only used for small retail payments. In countries with developed financial systems, between checkable bank deposits, giro accounts at post offices, money market accounts, charge cards, credit cards, debit cards, a wide range of private forms of E-money or digital cash cards, like the CashCard made by NETS or the EZ-link card, currency has become redundant as a means of payment for legitimate transactions goods and services and as a store of value for legitimately acquired financial wealth, except for the poorest members of society.

Although hard evidence is, for obvious reasons, difficult to come by, there is a reasonable presumption that the majority of US dollar and euro currency notes either are held abroad for legitimate reasons by citizens of countries where the authorities do not have a strong reputation for low and stable inflation, or are held for illegitimate reasons, both at home and abroad.

At the beginning of May 2009, the stock of euro currency notes and coin in circulation amounted to $€ 781 \mathrm{bn}$ (see Table 2 for the euro notes time series). Eurozone population is just under 310 million. This would mean that, if all euro notes were held inside the Eurozone, each man, woman and child would hold just over $€ 2,519$ in cash. At the end of March 2009, the stock of US\$ currency notes and coins outstanding amounted to just under US\$904bn (see Table 3). With a US population of around 306 million, this means that, if all US\$ currency notes were held inside the US, per capita US dollar holdings would be US\$2,950.

The US Treasury (2006) estimated that in 2005 about 50 percent of the stock of US currency was held abroad (see also Rogoff (1998, 2002)). Feige et. al. (2002) report estimates that between 30 and 69 percent of DM currency used to circulate outside the borders of Germany in the final years before the introduction of euro notes in 2002. It is 
unlikely that the share of euro notes held outside the euro area is significantly lower than the share of DMs held outside Germany towards the end of the DM's existence. ${ }^{9}$

Even assuming 50 percent (in value) of US dollar notes and euro notes are held abroad, it is clear that the distribution of the remaining domestically held notes is likely to be strongly skewed to the right: a small number of persons hold the vast majority of currency by value. Note from Tables 1 and 4, that the vast majority of euro and US\$ currency (by value) is held in the largest denominations. At the end of March 2009, fully $75 \%$ of US dollar currency was held in 100 dollar bills - the largest denomination still issued. In April 2009, 36 percent of euro notes was held in $€ 500$ notes. The $€ 500$, €200 and $€ 100$ denominations made up 59 percent of the stock of euro notes. The true retail notes, $€ 5, € 10$ and $€ 20$ just accounted for 10 percent of the total value of euro notes.

The only domestic beneficiaries from the existence of anonymity-providing currency are the underground economy - the criminal community: those engaged in tax evasion, money laundering and the financing of terrorism, and those wishing to store the proceeds from crime and the means to commit further crimes. The existence of fiat currency with legal tender status - an anonymity-providing secure store of value provided by the government represents a subsidy to criminal (illegal/underground) activity. It is particularly surprising to find so many large denomination bank notes, because these are unlikely to be held by poor and low-income households. The usefulness of currency as a means of payment and store of

\footnotetext{
${ }^{9}$ It is true that the euro is the domestic currency of 15 countries whose inhabitants could have held the DM as a foreign currency before the creation of the euro in 1999 (as well as of Germany). This would tend, cet. par. to make for a lower share of euro currency held outside the 16-country euro area than the share of DM currency held outside Germany, which is just one of the 16 euro area countries. Against this, the euro is already a more important official reserve currency than the DM ever was, and regional and global developments since 1999 have probably increased the demand for a safe and secure foreign currency alternative to domestic currency in many emerging markets.
} 
value for low income households is a standard argument in defence of the continued existence of currency.

Advanced industrial countries can move to electronic and bank-account-based means of payment and media of exchange without any significant transitional problems, permanent efficiency loss or adverse distributional implications. Negative interest rates on bank accounts and on balances outstanding on 'centralised or networked electronic media' like credit cards are as easy as positive interest rates. Debit cards simply transfer money between two accounts, both of which could pay negative interest rates and don't pose a problem. You could even retain a measure of anonymity and have 'cash-on-a-chip cards', which, whenever the balance on the card is replenished by drawing funds from some account, calculate the average balance held on the cash card since the last replenishment and arrange for the appropriate interest rate (positive or negative) to be applied.

Because currency is a redundant or dominated medium of exchange/means of payment, except possibly for the smallest denominations, which may still be useful for small retail transactions (up to perhaps $€ 20$ or US\$20, say), what accounts for its continuing existence and popularity? The only rational argument I can see is that seigniorage, the resources that can be appropriated through the issuance of non-interest-bearing legal tender, is a valuable source of revenue, either for the central bank or for its beneficial owner, typically the ministry of finance or Treasury. From Table 2, over the year 2007, the Eurosystem earned $€ 49$ bn as seigniorage from the issuance of bank notes, and over 2008 , as much as $€ 86 \mathrm{bn}$. From the first week of June 2007 till the first week of June 2008, US currency in circulation increased by US\$10.5bn. Between the first week of June 2008 and the first week of June 2009, US currency in circulation increased by US $\$ 85.5 \mathrm{bn}$.

Is it likely that the social benefits from this seigniorage revenue, together with the convenience benefits that currency still may yield when used in legitimate small retail 
transactions and held in small savings balances, exceed the social costs of the incremental tax evasion, money laundering, terrorism and other criminality encouraged by the anonymity and privacy provided by currency?

Should fiat currency be abolished, the loss of these retail transactions benefits could be compensated for by offering free accounts with the central bank to all legal residents. These accounts could be administered through commercial banks, post offices and other retail facilities. These accounts, being registered instruments, could, of course, pay a positive, zero or negative rate of interest, as required.

Should the government decide to abolish government base money, it is possible that the private sector would start supplying a close functional substitute, as it did before such practices were made illegal and the government established its monopoly of currency issuance. If there were no enforceable legal prohibition against this private issuance, it would lead to the case discussed in Section 4.4 below.

By abolishing currency and introducing a close substitute on which interest, positive or negative can be paid, the authorities can remove the lower bound on the short nominal interest rate by adopting a simple rule for the nominal interest rate on money, such as the one given in equation (46). Note that if the policy-determined wedge between the two interest rates were zero, $\omega=0$, Friedman's optimal quantity of money (OQM) rule would be automatically implemented all the time (Friedman (1969)).

$$
\begin{aligned}
& i^{M}=i-\omega \\
& \omega \geq 0
\end{aligned}
$$

\subsection{Taxing currency}

As discussed in the Introduction, paying interest, positive or negative requires individual notes (or even coins) to be identifiable as current on any interest due. With the identity of the currency unknown to the issuer of the currency, it must be possible to identify 
the individual notes and coins as being up-to-date on interest due or owed. When interest is received or paid the notes must be marked somehow. Historical proposals for achieving this often involved stamping currency. Silvio Gesell (1916) is an early example of such a proposal, which was also supported by Irving Fisher (1933). In the case of conventional bearer bonds, coupons were physically clipped from the bond document or certificate.

Another variant is to give the currency note an expiration date. Unless this scrip money is stamped no later than the expiration date, it loses its legal tender status. When it is stamped, the negative interest can be collected by the issuer or his agent. Unstamped currency ceases to be recognised as money by the authorities and will thus, in the eyes of the proponents of scrip money, become worthless.

The reason this proposal is incomplete is that the value of fiat money is what people believe it to be and are willing to exchange it for. No doubt losing legal tender status might undermine people's confidence in a currency, but many financial instruments have served as means of payment, medium of exchange and store of value without having legal tender status. If enough private agents were to consider a $€ 10$ note that had expired (had not been stamped) to be worth as much as a $€ 10$ note that was current on interest (had been stamped), then the stamped and unstamped notes would indeed have the same value (exchange for the same bundles of goods and services and for each other).

So to ensure that expired (unstamped) currency does not continue to circulate on a par with current (stamped) currency, a penalty must be imposed on those caught with expired (unstamped) currency. The penalty must be sufficient to induce those holding the currency to pay the currency tax. Confiscation of the expired (unstamped) notes, or a fine would be possible enforcement mechanisms of a negative interest rate on currency. This would involve administrative costs and rather intrusive policing, possibly with random spot checks and 
searches etc. Such monitoring and enforcement of negative interest rates (taxes) on currency would be a rather illiberal policy and unlikely to be popular.

An operational proposal for taxing currency mentioned by Mankiw (2009), who attributes it to one of his graduate students, appears to get around this monitoring and enforcement problem. All currency notes have a serial number ending in an integer from 0 to 9. All currency notes also should have a year printed on them (most I know of do). Once a year, on a fixed date, the central bank randomly selects an integer from 0 to 9 . All currency notes ending in that integer, printed in that year or earlier, lose their legal tender status and are no longer redeemable/exchangeable at the central bank or its agents for anything else.

The expected nominal interest rate on currency is therefore $-10 \%$ under this scheme, which is effectively a negative interest rate version of the British Premium Bond - a government bond that bears no interest or capital gains but enters the holder into lotteries, based on the serial number of the bond. It can also be viewed as a lottery version of putting an expiration date on all currency notes and charging $10 \%$ of face value tax on each note.

However, the Mankiw scheme falls foul of the same problem that currency with an expiration date falls foul of, unless there is external enforcement. The value of fiat money is what people think it is. If the central bank randomly selects 7 as the unlucky number this year and I own a $€ 100$ note whose serial number ends in 7 , I may still be able to purchase goods and services worth $€ 100$ with that note, provided other private agents are willing to accept it as being worth that much. Legal tender status or convertibility into other government notes at the central bank is not necessary for fiat money to have value. Some form of monitoring currency holdings and a penalty for those caught with expired currency (such as the threat of confiscation plus a fine) are likely to be necessary to make Mankiw's scheme work. 
If the authorities are willing to incur the administrative and surveillance costs, and to incur the political unpopularity likely to be associated with taxing currency, they could eliminate the lower bound on the risk-free one-period nominal interest rate on non-monetary assets, by adopting a rule for the one-period own rate of interest on currency like the one specified in equation (46).

\subsection{Unbundling the numéraire and the medium of exchange/means of}

\section{payment}

A third way to eliminate the lower bound on the short nominal interest rate was suggested by Eisler (1933) (see also Einaudi (1953) and Gaitskell (1969)). It involves decoupling the numéraire function from the currency, which would retain its numéraire and means of payment/medium of exchange roles. A simple way to implement this decoupling, which involves the abolition of the old government-issued fiat currency and its replacement by a new government-issued fiat currency is discussed first. Many interesting variations on this theme exist, however, and I shall introduce some of these later in Section 4.

The first step is to abolish the euro currency, by withdrawing all euro notes and coins. The next step is the introduction of a new currency, which I shall call the wim (in honour of Wim Duisenberg, the first President of the European Central Bank). The euro is kept as the numéraire for wage and price contracts. This is an assumption that leads to an interesting model only if it is plausible.

I believe that there are many ways in which, despite the abolition of physical euro currency, the authorities can encourage the continued use of the euro as numéraire. The government could require all contracts involving the state to be denominated in euro. It could present tax claims and require tax returns in euro, and require tax payments using euro- 
denominated instruments. Going beyond that, it could ban bank deposits denominated in wim. As a last resort it could declare all wim-denominated contracts not to be enforceable in Eurozone courts.

In the model, private agents and the authorities are free to issue and hold contingent claims denominated in both wim and euro. Specifically, there are both safe one-period wimdenominated bonds and safe one-period euro-denominated bonds.

As there is no longer any euro currency, there no longer is a lower bound on euro interest rates. There is a lower bound on wim interest rates, because there is wim currency. The government sets the sequence of spot exchange rates, or of spot and forward exchange rates, between the euro and the wim.

\subsubsection{The private sector in the wim currency economy}

The household optimisation problem changes slightly. Let $M_{t}^{*} \geq 0$ be the nominal stock of wim currency at the end of period $t, S_{t}$ the period $t$ spot exchange rate between the euro and the wim (number of wim per euro), $F_{t+1, t}$ the one-period forward exchange rate between the euro and the wim (number of wim per euro), $i_{t+1, t}^{*}$ the one-period safe nominal interest rate on wim-denominated bonds, $i_{t+1, t}^{M^{*}}$ the one-period own rate of interest on wim currency, $I_{t_{1}, t_{0}}^{*}$ the nominal wim stochastic discount factor between periods $t_{1}$ and $t_{0}, R_{t_{1}, t_{0}}^{*}$ the real wim stochastic discount factor between periods $t_{1}$ and $t_{0}, P^{*}$ the wim general price level, $\Pi_{t_{1}, t_{0}}^{*} \equiv \frac{P_{t_{1}}^{*}}{P_{t_{0}}^{*}}$ the wim inflation factor ( 1 plus the wim inflation rate to the power $\left.t_{1}-t_{0}\right)$ and $\Sigma_{t_{1}, t_{0}} \equiv \frac{S_{t_{1}}}{S_{t_{0}}}$ the wim exchange rate depreciation factor between periods $t_{1}$ and $t_{0}$. 
If there is to be no pure (risk-free) arbitrage possibility in this economy, the "law of one price" will have to hold, that is the wim price of goods is the euro price of the good times the wim-euro exchange rate:

$$
P_{t}^{*}=S_{t} P_{t}
$$

This implies

$$
\Pi_{t_{1}, t_{0}}^{*}=\Pi_{t_{1}, t_{0}} \Sigma_{t_{1}, t_{0}}
$$

Also note that:

$$
\begin{aligned}
& \frac{1}{1+i_{t+1, t}^{*}} \equiv E_{t} I_{t+1, t}^{*} \\
& \text { and } \\
& \frac{1}{1+r_{t+1, t}^{*}} \equiv E_{t} R_{t+1, t}^{*}
\end{aligned}
$$

Beginning-of-period nominal financial wealth (measured in wim) in period $t$ is denoted $W_{t}^{*}$. The wim value in period $t$ (including interest or other income paid) of the portfolio of financial assets other than money purchased in period $t-1$ is denoted $A_{t}^{*}$. These financial aggregates are related as follows:

$$
W_{t}^{*} \equiv A_{t}^{*}+\left(1+i_{t, t-1}^{M^{*}}\right) M_{t-1}^{*}
$$

The household's optimisation problem in the wim currency economy becomes

$$
\begin{gathered}
U_{0}=E_{0} \sum_{t=0}^{\infty} \beta^{t}\left[\frac{1}{1-\gamma} c_{t}^{1-\gamma}+\eta \frac{1}{1-\gamma}\left(\frac{M_{t}^{*}}{S_{t} P_{t}}\right)^{1-\gamma}\right] \\
E_{t} I_{t+1, t}^{*} W_{t+1}^{*} \equiv W_{t}^{*}+S_{t} P_{t}\left(y_{t}-\tau_{t}-c_{t}\right)-\left(\frac{i_{t+1, t}^{*}-i_{t+1, t}^{M^{*}}}{1+i_{t+1, t}^{*}}\right) M_{t}^{*} \\
E_{0} \lim _{\ell \rightarrow \infty} I_{\ell+1, t}^{*} W_{\ell}^{*} \geq 0 \\
M_{-1}^{*}=\bar{M}_{-1}^{*}>0 \\
A_{0}^{*}=\bar{A}_{0}^{*}
\end{gathered}
$$


The optimality conditions of this optimisation problem imply the following relations hold:

$$
\begin{gathered}
c_{t}^{-\gamma}=\beta\left(1+r_{t+1, t}^{*}\right) E_{t} c_{t+1}^{-\gamma} \\
\frac{M_{t}^{*}}{S_{t} P_{t}}=\left[\eta\left(\frac{1+i_{t+1, t}^{*}}{i_{t+1, t}^{*}-i_{t+1, t}^{M^{*}}}\right)\right]^{1 / \gamma} c_{t} . \\
1+i_{t+1, t}=\frac{S_{t}}{F_{t}}\left(1+i_{t+1, t}^{*}\right) \\
\frac{1+i_{t+1, t}}{1+i_{t+1, t}^{*}}=E_{t}\left(\Sigma_{t+1, t}^{-1}\right)+\frac{\operatorname{Cov}_{t}\left(c_{t+1}^{-1} \Pi_{t+1, t}^{-1}, \Sigma_{t+1, t}^{-1}\right)}{E_{t}\left(c_{t+1}^{-1} \Pi_{t+1, t}^{-1}\right)} . \\
\lim _{T \rightarrow \infty} E_{t}\left(\frac{\beta^{T}}{c_{t+T}^{\gamma}} \frac{M_{t+T}^{*}}{S_{t+T}^{*} P_{t+T}}\right)=0 \\
1+r_{t+1, t}^{*}=\left(1+i_{t+1, t}^{*}\right)\left(E_{t} \Pi_{t+1, t}^{*-1}+\frac{\operatorname{Cov}_{t}\left(\Pi_{t+1, t}^{*-1}, c_{t+1}^{-\gamma}\right)}{E_{t} c_{t+1}^{-\gamma}}\right)
\end{gathered}
$$

In the wim currency economy, the real interest rate on euro bonds is the same as the real interest rate on wim bonds (equation (57)). This does not mean, of course, that the wim currency economy behaves identically to the euro currency economy. While the real interest rate on euro bonds is the same as the real interest on wim bonds in the wim currency economy, this common real interest rate will be different from the real interest rate that would prevail in the euro currency economy (starting from the same initial conditions) if there is any probability that the lower bound constraint on the short nominal interest rate would become binding in the euro currency economy.

From the money demand function (55), it is clear that there is a lower bound on the one-period wim interest rate: 


$$
i^{*} \geq i^{M^{*}}
$$

but since there is no euro currency in the wim currency economy, there is no lower bound on the one-period euro nominal interest rate, $i$.

Unsurprisingly, covered interest parity (CIP) holds in this economy between euro interest rates and wim interest rates (equation (56)). From equation (58), uncovered interest parity (UIP) holds only if the risk-premium on euro interest rates, $\frac{\operatorname{Cov}_{t}\left(c_{t+1}^{-1} \Pi_{t+1, t}^{-1}, \Sigma_{t+1, t}^{-1}\right)}{E_{t}\left(c_{t+1}^{-1} \Pi_{t+1, t}^{-1}\right)}$, is zero. ${ }^{10}$ In that case, the euro interest rate (approximately) equals the wim interest rate plus the expected proportional rate of appreciation of the wim in terms of the euro, $E_{t}\left(\Sigma_{t+1, t}^{-1}\right)-1$.

Since the euro remains the numéraire and invoicing currency for wage and price transactions, the Phillips curve is unchanged in the wim currency economy from what it is in the euro currency economy (equations (18) and (19)).

\subsubsection{The government in the wim currency economy}

The authorities spend and tax as before. They issue wim currency and issue both wim and euro one-period bonds. Their period budget identity is given in (62) and their solvency constraint in (63).

$$
\begin{gathered}
\frac{M_{t}^{*}}{S_{t}}+B_{t}+\frac{B_{t}^{*}}{S_{t}} \equiv\left(1+i_{t, t-1}^{M^{*}}\right) \frac{M_{t-1}^{*}}{S_{t}}+\left(1+i_{t, t-1}\right) B_{t-1}+\left(1+i_{t, t-1}^{*}\right) \frac{B_{t-1}^{*}}{S_{t}}+P_{t}\left(g_{t}-\tau_{t}\right) \\
E_{0} \lim _{t \rightarrow \infty} I_{t+1,0}\left[\left(1+i_{t+1, t}\right) B_{t}+\left(1+i_{t+1, t}^{*}\right) \frac{B_{t}^{*}}{S_{t}}\right] \leq 0 .
\end{gathered}
$$

For concreteness assume the government applies the same rule for its lump-sum taxes it used in the euro currency economy, that is,

$$
{ }^{10} \text { Under UIP, } F_{t+1, t}=\left(E_{t}\left(\frac{1}{S_{t+1}}\right)\right)^{-1} \text {. }
$$




$$
\tau_{t}=g_{t}-\frac{1}{S P_{t}}\left(M_{t}^{*}-\left(1+i_{t, t-1}^{M^{*}}\right) M_{t-1}^{*}-\left(1+i_{t, t-1}^{*}\right) B_{t-1}^{*}-S_{t}\left(1+i_{t, t-1}\right) B_{t-1}\right) \quad t \geq 0
$$

The Taylor rule for the euro nominal interest rate in the wim currency economy looks as follows:

$$
1+i_{t+1, t}=\beta^{-1} \hat{\Pi}+\phi\left(E_{t} \Pi_{t+1, t}-\hat{\Pi}\right)
$$

To complete the policy regime (assuming exogenous real public spending as before), I assign a simple quantitative easing rule for wim currency, when the lower bound constraint in the wim nominal interest rate binds:

$$
\text { If } i_{t+1, t}^{*}=i_{t+1, t}^{M^{*}} \text { then } M_{t+1}^{*}=\left(1+\mu_{t+1, t}^{*}\right) M_{t}^{*}
$$

where $\left\{\mu_{t+1, t}^{*}>-1 ; t \geq 0\right\}$ is, for simplicity, an exogenous sequence of proportional growth rates of the nominal stock of wim currency.

Comparing (65) with the Taylor rule for the euro nominal interest rate in the euro currency economy, (25), we note that, because the lower bound constraint on the euro nominal interest rate has been removed, the interest rate now does not switch from the Taylor rule to the quantitative easing rule given by the second line of equation (25) and by equation (26).

We can represent the monetary authority as having four potential instruments in any given period, $t$ : the short nominal euro interest rate, $i_{t+1, t}$, the one-period wim nominal interest rate, $i_{t+1, t}^{*}$, the spot exchange rate between the euro and the wim, $S_{t}$ and the oneperiod forward exchange rate between the euro and the wim, $F_{t+1, t}$ The interest rate on wim currency, $i_{t+1, t}^{M^{*}}$ is, by assumption, not an instrument. All we need is for it to be exogenous. In practice, it is equal to zero. When the lower bound constraint on the short nominal wim 
interest rate binds, $i_{t+1, t}^{*}=i_{t+1, t}^{M^{*}}$, the proportional rate of growth of the stock of wim currency, $\mu_{t+1, t}^{*}$ becomes an instrument (quantitative easing).

\subsubsection{Equilibrium}

Goods market equilibrium in the wim currency economy is given by the same equation (27) as in the euro currency economy. The asset market equilibrium condition, however, changes from equation (28) to

$$
A_{t}^{*}=\left(1+i_{t, t-1}\right) S_{t} B_{t-1}+\left(1+i_{t, t-1}^{*}\right) B_{t-1}^{*}
$$

\subsubsection{How monetary policy is implemented in the wim currency economy}

With $i_{t+1, t}, i_{t+1, t}^{*}, S_{t}$ and $F_{t+1, t}$ as the potential monetary instruments in any period $t$ and with covered interest parity (equation (56)) constraining the four instruments, only three of the four can be chosen independently. In the model under consideration, the short nominal euro interest rate is determined by the Taylor rule (65), regardless of whether this takes the euro nominal interest rate into negative territory. There are infinitely many combinations of rules for the spot and forward exchange rates and the wim rate of interest that are consistent with equilibrium. Any given equilibrium sequence for the real variables and for euro nominal interest rates and euro inflation rates can also be supported by infinitely many different combinations of spot and forward exchange rates and wim rates of interest. I will start by considering a simple, transparent example.

The rule for the one-period risk-free wim nominal interest rate on non-monetary securities satisfies (68), that is, when the euro nominal interest rate set by the Taylor rule (or any other rule) exceeds the lower bound on the wim nominal interest rate, the authorities set the euro interest rate and the wim interest rate equal to each other. When the euro nominal interest rate is equal to or less than the lower bound on the wim nominal interest rate, the 
authorities set the wim nominal interest rate equal to its lower bound, $i^{M^{*}}$. This ensures that the lower bound on the wim nominal interest rate, (61), is never violated.

$$
\begin{aligned}
i_{t+1, t}^{*} & =i_{t+1, t} \text { if } i_{t+1, t}>i_{t+1, t}^{M^{*}} \\
& =i_{t+1, t}^{M^{*}} \text { if } i_{t+1, t} \leq i_{t+1, t}^{M^{*}}
\end{aligned}
$$

From the covered interest parity condition, we know that $\frac{F_{t+1, t}}{S_{t}}=\frac{1+i_{t+1, t}^{*}}{1+i_{t+1, t}}$, so under the rule given by (68),

$$
\begin{aligned}
& \frac{F_{t+1, t}}{S_{t}}=1 \quad \text { if } i_{t+1, t}>i_{t+1, t}^{M^{*}} \\
& \frac{F_{t+1, t}}{S_{t}}=\frac{1+i_{t+1, t}^{M^{*}}}{1+i_{t+1, t}} \text { if } \quad i_{t+1, t} \leq i_{t+1, t}^{M^{*}}
\end{aligned}
$$

With $i_{t+1, t}$ and $i_{t+1, t}^{*}$ as instruments (subject to $i_{t+1, t}^{*} \geq i_{t+1, t}^{M^{*}}$ ), the forward premium factor on the euro, $\frac{F_{t+1, t}}{S_{t}}$, is market-determined by covered interest parity. The authorities can set either the spot or the forward exchange rate, with the remaining one residually determined.

As long as the lower bound constraint on the wim nominal interest rate is not binding, the spot rate equals the forward rate; when the lower bound constraint on the wim nominal interest rate $i$ s binding, the euro stands at a proportional forward premium to the wim equal to the difference between the interest rate on wim currency and the interest rate on one-period safe euro bonds. Consider the practically relevant case where the interest rate on wim currency is zero $\left(i_{t+1, t}^{M^{*}}=0\right)$. It follows that, if the (zero) lower bound constraint on wim interest rates is binding $\left(i_{t+1, t}^{*}=i_{t+1, t}^{M^{*}}=0\right)$, the relationship between the spot and forward exchange rates is given by

$$
\frac{F_{t+1, t}}{S_{t}}=\frac{1}{1+i_{t+1, t}}
$$


So if the Taylor rule (65) were to imply a negative value for the short nominal euro rate of interest, $i_{t+1, t}$, there would be no profitable arbitrage possibilities borrowing at the negative euro rate and lending at the zero wim rate, because the forward premium on the euro equals the wim-euro interest differential. If there is no currency risk premium ( $\left.\operatorname{Cov}_{t}\left(c_{t+1}^{-1} \Pi_{t+1, t}^{-1}, \Sigma_{t+1, t}^{-1}\right)=0\right)$, the expected proportional rate of appreciation of the euro vis-à-vis the wim would equal the wim-euro interest differential, that is, UIP holds $F_{t+1, t}=\left(E_{t}\left(\frac{1}{S_{t+1}}\right)\right)^{-1}$. If UIP holds, when the zero lower bound constraint on wim interest rates is binding, a negative euro nominal interest rate is consistent with portfolio balance provided the expected proportional appreciation rate of the euro vis-à-vis the wim exactly compensates for the negative interest rate on the euro:

$$
\frac{1+i_{t+1, t}}{1+i_{t+1, t}^{*}}=1+i_{t+1, t}=E_{t}\left(\frac{S_{t}}{S_{t+1}}\right)
$$

So if $i_{t+1, t}<0$, then $E_{t}\left(\frac{S_{t}}{S_{t+1}}\right)=1+i_{t+1, t}<1$.

\subsubsection{Would the numéraire 'follow the currency'?}

Key to the effectiveness of the unbundling solution is the assumption that the euro remains the numéraire for wage and price contracting, even after the euro currency has been abolished and replaced by the wim currency, that is, that the euro price level Phillips curve (32) remains the operational one and that the inflation rate of concern to the authorities is the proportional rate of increase in the euro general price level, as exemplified in the wim currency model by the continued relevance of the Taylor rule for the euro interest rate (without the lower bound), given in (65). 
If the numéraire instead were to 'follow the currency' and a wim price level Phillips curve, we would have achieved no more than a change in the unit of account for the euro currency economy, like the change from old French francs to new French francs in January 1960, with 100 old French francs - 1 new French franc. The zero lower bound would continue to exist in the new French franc economy as it had in the old French franc economy.

Monetary economics has very little to say about what or who determines what the numéraire is or about what physical, fiat or imaginary substances serve as numéraire. Even the great monetary thinkers of the past had little to contribute, other than anecdotes or appeals to common sense (see e.g. Patinkin (1965), Hicks (1967), Niehans (1978)).

Fundamentally, what serves as unit of account (or multiple units of account) in an economy is determined through a collective but uncoordinated, decentralised social choice of the agents making up the economy. The authorities can certainly encourage the use of a particular financial instrument as unit of account. As pointed out earlier, the government could require contracts involving the state to be denominated in euro, even after the abolition of the euro currency and the introduction of the wim currency. It could require taxes to be reported in euro and to be paid in euro-denominated instruments. It could even impose a ban on bank deposits denominated in wim or declare all wim-denominated contracts not to be enforceable in Euro Area courts. What does history tell us happened when numéraire and currency parted ways?

The unit of account used most widely in a society need not be the unit of denomination of whatever financial instruments are used as means of payment and medium of exchange. Everyone is familiar with the Guinea, which was neither the official unit of account used by the UK monetary authorities in their transactions, nor a medium of exchange/means of payment after 1813, but continued to be used as the numéraire in auction houses and expensive and pretentious shops until decimalisation in 1971. 
The history of primitive monies, described in Paul Einzig's book (Einzig (1949)) contains many examples of the uncoupling of the official numéraire function both from the private numéraire and from the medium of exchange/means of payment function. Medieval Iceland had a cattle, a cloth and a fish-standard. The monetary unit known as the kugildi was defined precisely in terms of a standardized cow. It is doubtful that the kugildi could ever have been extensively used as a medium of exchange. Einzig reports that in documents it was often explicitly stated that "...payment fixed in kugildi was actually to be made in metallic money or in other form" (Einzig (1949, p. 260)). Plain home-woven woollen cloth (wadmal ) served as a general standard of value (unit of account) throughout the Icelandic medieval period.

Wadmal was used to determine the amount of wergeld (compensation for wrongful death)y to be paid and for the valuation of damages. Taxes were fixed in wadmal. Unlike kugildi, wadmal was widely used as a medium of exchange. There was a fixed legal exchange rate between kugildi and wadmal. In the 15th century, dried stockfish appears to have been used widely in Iceland as a unit of account. Einzig expresses doubt as to whether it was widely used as a medium of exchange (Einzig (1949, p. 262)), and one can only hope he is right in this. In the case of the wadmal, it is interesting that, while the authorities fixed taxes in terms of wadmal, there was no monetary authority with a monopoly of the supply of wadmal. Every home with a spinning wheel and a hand-loom could become a private mint.

In more recent times, and even in the fiat money era, there are examples that support the view that the unit of account used most widely in a society need not be the official monetary unit used to define (some of) the liabilities of the central bank. In countries with very high inflation or hyperinflation, the unit of account has often been a more stable foreign currency, although the means of payment/medium of exchange for small-scale retail transactions remained the national currency. For instance, the US dollar played that role in 
Israel during the inflation surge that prompted the successful stabilisation plan of July 1985 and in Peru during the hyperinflation that led to the successful stabilisation package of August 1990. The US dollar was used as the numéraire for posting retail prices, but after a hasty verification of the current exchange rate, retail transactions tended to be settled in shekels, respectively intis or soles.

An interesting, albeit short-lived monetary experiment took place in the eleven countries that made up the Eurozone between the date of the official designation of the euro as the new numéraire on January 1, 1999 and the introduction of the physical euro currency around January 1, 2002. ${ }^{11}$ During that three-year period, the national legacy currencies continued to function as media of exchange and means of payment for cash transactions.

Officially, however, the euro was the numéraire from January 1, 1999 on, and the national currencies represented inconvenient non-integer denominations of the euro. In reality, however, the national legacy currencies continued to be used overwhelmingly as the unit of account not just in transactions involving payment with these national legacy currencies, but also in contracts that might be settled using non-cash means of payment. The numéraire in the bulk of private transactions (cash and non-cash) stayed with the means of payment/medium of exchange despite the introduction of the new numéraire, the euro. In practice, until euro currency was introduced and the national legacy currencies lost their legal tender status, the euro was treated as an inconvenient non-integer denomination of the national legacy currencies.

All three methods for eliminating the lower bound on nominal interest rate make it possible to target true price stability $(\hat{\Pi}=1)$ or any low rate of inflation without fear of hitting the lower bound. The inflation targets of most real-world central banks, including the

\footnotetext{
${ }^{11}$ Greece became the $12^{\text {th }}$ Euro Area member on January 1, 2001.
} 
ECB (close to but below 2 percent per annum for the HICP), the Bank of England (2 percent per annum for the CPI) and the Fed (an informal target for core CPI inflation of between 1.5 and 2.0 percent per annum) are for positive rates of inflation rather than for a zero rate of inflation for two reasons. The first is that there are biases in the price indices used to measure inflation that cause the measured rate of inflation to overstate the true rate of increase in the cost of living. The second is that the asymmetry in the policy maker's choice set created by the zero lower bound on nominal interest rates makes it desirable to target an inflation rate somewhat higher than the one that would be targeted without the existence of the zero lower bound. This second argument for targeting a positive rather than a zero rate of inflation would no longer apply.

Both taxing currency and unbundling numéraire and currency would permit the authorities to implement Friedman's optimal quantity of money (OQM) rule without this constraining the rate of inflation they target.

When currency is taxed, the tax rate is $-i^{M}$. The OQM rule, which requires a zero pecuniary opportunity cost of holding base money, that is, $i=i^{M}$, still leaves the nominal interest rate free to target any rate of inflation. In terms of equation (46), we set $\omega$, the wedge between the nominal bond interest rate and the nominal interest rate on currency, equal to zero.

When numéraire and currency are decoupled, the OQM is satisfied with the wim rate of interest, $i^{*}$ equal to the (exogenous) rate of interest on wim currency, $i^{M^{*}}$ (which could be zero without affecting the argument). Clearly, this pins down the rate of inflation in terms of wim, $\Pi^{*}$. In the deterministic flexible price version of the model with constant values of the exogenous variables, the stationary fundamental solution would have the wim inflation rate equal to minus the real interest rate: $\Pi^{*}=\frac{1}{1+r^{*}}=\frac{1}{1+r}=\beta^{-1}$. However, the euro rate of 
inflation can be anything the authorities want it to be, because the euro nominal interest rate can be set freely (because of CIP): $\Pi=\beta(1+i)$.

\section{Alternative implementations and interpretations of the unbundling of numéraire and currency}

\subsection{Retaining the old currency but no longer supplying it on demand at a fixed parity with bank reserves at the central bank}

This is no more than a re-interpretation of the wim currency economy. It interprets the wim currency model as a real-time evolution of the euro currency model, modified with the assumption that the authorities no longer exchange one euro worth of euro currency notes (at face value) for one euro worth of euro-denominated bonds when they wish to set the interest rate on euro-denominated bonds at a zero or negative value.

More precisely, in the euro currency economy, let the monetary base consist of currency and bank reserves with the central bank: $M=N+D$. Assume that the interest rate on euro currency is zero and that the interest rate on euro reserves is the one-period nominal euro bond rate: $i^{N}=0$ and $i^{D}=i$. Assume for simplicity that only euro currency appears in the direct utility function: $U_{0}=E_{0} \sum_{t=0}^{\infty} \beta^{t}\left[\frac{1}{1-\gamma} c_{t}^{1-\gamma}+\eta \frac{1}{1-\gamma} \ln \left(\frac{N_{t}}{P_{t}}\right)_{t}^{1-\gamma}\right]$. Bank reserves are perfect substitutes for one-period euro bonds. As long as the zero lower bound on the euro nominal interest rate is not binding, the authorities supply euro currency on demand at a fixed exchange rate with euro bonds: $S_{t}=S_{t+1}=F_{t}$ as long as $i>0$. Starting from a position like the present, when negative nominal interest rates have not occurred in the past, the natural 
fixed exchange rate would be 1 . Note that in this interpretation it is the euro bond that is the numéraire in terms of which prices and wages are set, not the euro currency.

If in period $t$ the zero lower bound on the euro nominal interest rate becomes a binding constraint, I assume, for simplicity, that the authorities set the period $t$ spot exchange rate $S_{t}$ at the same value as the period $t-1$ forward rate, that is, $S_{t}=F_{t, t-1}$ (which would equal 1 in the current historical episode), but the period $t$ forward rate will now be set at the level required to produce that value of the forward premium for the euro bond vis-à-vis the euro currency that prevents arbitrage between euro bonds and euro currency.

In general, the authorities would set the interest rate on euro bonds and the spot and forward exchange rates between euro bonds and euro currency to satisfy:

$$
\begin{aligned}
& \frac{F_{t+1, t}}{S_{t}}=1 \quad \text { if } \quad i_{t+1, t}>0 \\
& \frac{F_{t+1, t}}{S_{t}}=\frac{1}{1+i_{t+1, t}} \text { if } \quad i_{t+1, t} \leq 0
\end{aligned}
$$

Note that since the spot exchange rate is a policy instrument, we don't have to worry about appropriate boundary conditions to pin down the initial value of the exchange rate. This can be given by history (at 1 today) or by government fiat.

\subsection{A floating exchange rate version of the euro bond and euro currency model}

An appropriate terminal condition for the spot exchange rate does become an issue in the floating exchange rate version of the model considered in the previous subsection.

Instead of viewing the exchange rate of the euro bond vis-à-vis the euro currency as the instrument and the stock of euro currency as endogenously determined (or demanddetermined), we can have the authorities select some trajectory (or rule) for the nominal stock 
of euro currency whenever they wish to set a negative interest rate for euro bonds. The exchange rate of euro-bonds vis-à-vis euro currency could then be determined by a competitive market process.

I continue to assume that the interest rate on euro bonds is determined by the Taylor rule (65). Should the Taylor rule take the nominal interest rate for euro bonds into positive territory, the exchange rate would be fixed again. If period $t$ is the first period the nominal interest rates on euro bonds becomes positive again after a spell in zero or negative territory, I assume, for simplicity, that $S_{t}=F_{t, t-1}$. When the interest rate on euro bonds is positive, the exchange rate between the euro bond and the euro currency is fixed and the euro currency stock is demand-determined.

It is obvious that the exchange rate equations in (72), which were constructed to avoid arbitrage possibilities, will also characterise a competitive market solution for the exchange rate. In this case, however, we need a boundary condition, in the form of a terminal condition, to pin down the initial value of the exchange rate. The reason for this is obvious from the no-arbitrage equilibrium condition (58), which (because the interest rate on currency is zero) allows the exchange rate process (72) to be written as:

$$
\begin{aligned}
& F_{t+1, t}=S_{t} \text { if } i_{t+1, t}>0 \\
& 1+i_{t+1, t}=E_{t}\left(\frac{S_{t}}{S_{t+1}}\right)+\frac{\operatorname{Cov}_{t}\left(c_{t+1}^{-1} \Pi_{t+1, t}^{-1}, S_{t} / S_{t+1}\right)}{E_{t}\left(c_{t+1}^{-1} \Pi_{t+1, t}^{-1}\right)} \text { if } i_{t+1, t} \leq 0 .
\end{aligned}
$$

This shows that the current spot exchange rate depends on the entire future (stochastic) path of euro interest rates and risk-premia, and on a terminal boundary condition for this stochastic exchange rate process. As there is no easy intuitive way to specify a terminal boundary condition for the spot exchange rate, I finessed the problem by assuming that the authorities set the initial value of the spot exchange rate during any period when the 
euro bond interest rate goes zero or negative, if in the previous period it was positive. All subsequent exchange rates are market-determined. Concretely, I assumed that the authorities set the initial value of the spot exchange rate in that period at the value of the one-period forward exchange rate from the previous period. So the exchange rate satisfies (as in the managed exchange rate regime of the previous subsection:

$$
\begin{aligned}
& S_{t+1}=F_{t+1, t}=S_{t} \text { if } i_{t+1, t}>0 \\
& S_{t+1}=F_{t+1, t}=S_{t} \text { if } i_{t+1, t} \leq 0 \text { but } i_{t, t-1}>0 \\
& 1+i_{t+1, t}=E_{t}\left(\frac{S_{t}}{S_{t+1}}\right)+\frac{\operatorname{Cov}_{t}\left(c_{t+1}^{-1} \Pi_{t+1, t}^{-1}, S_{t} / S_{t+1}\right)}{E_{t}\left(c_{t+1}^{-1} \Pi_{t+1, t}^{-1}\right)} \text { if } i_{t+1, t} \leq 0 \text { and } i_{t, t-1} \leq 0 .
\end{aligned}
$$

\subsection{A floating exchange rate version of the wim currency model with pet} rocks

There is nothing in the logic of the model that requires the fiat money to be provided by the government. Assume that instead of fiat paper or electronic currency, there is some exogenous supply of intrinsically worthless objects, say 'pet rocks' like rai, the stone money of the Yap islands. These are large, doughnut-shaped carved disks, usually of calcite, that can be up to 4 meters in diameter, although most are much smaller. Money would disappear from the government budget constraint (62), which would become

$$
B_{t}+\frac{B_{t}^{*}}{S_{t}} \equiv\left(1+i_{t, t-1}\right) B_{t-1}+\left(1+i_{t, t-1}^{*}\right) \frac{B_{t-1}^{*}}{S_{t}}+P_{t}\left(g_{t}-\tau_{t}\right)
$$

and from the government tax rule (64), which would become $\tau_{t}=g_{t}-\frac{1}{S P_{t}}\left(\left(1+i_{t, t-1}^{*}\right) B_{t-1}^{*}-S_{t}\left(1+i_{t, t-1}\right) B_{t-1}\right) \quad$. The government solvency constraint (63) would be unaffected. Note that the pet rock money is a true 'outside asset', an asset to the owner but not a liability of anyone else - 'nature' was the issuer. 
As long as there is an exhaustive initial assignment of property rights for the pet rocks, the household optimisation problem would not be affected. Interest on this pet rock

currency is zero. In the case of rai, the total stock is given, but in principle the supply could change exogenously over time (if meteorites were the currency, say) as long as any addition to the stock has an exhaustive assignment of property rights.

In the pet rock currency model, pinning down the initial value of the exchange rate between one unit of euro bonds and a unit of pet rocks, during a period when the interest rate on euro bonds goes negative after being positive in the previous period, would again require either a terminal boundary condition, or a fixing by the government. In the case of fiat euro currency, the authorities certainly have the ability to set the value of the exchange rate in any period, as they can issue any (non-negative) amount of currency. This is not true in the case of pet rocks whose aggregate supply is given and finite. All I can offer at this point is that the solution for the stochastic exchange rate path given in (74) is $a$ solution for the case where currency is pet rocks. There are bound to be many other solutions as well, however.

\subsection{A private currency interpretation of the model}

Assume that, in the euro currency economy, the government abolishes its fiat currency and retires all notes and coin. Assume that the prohibition against the private issuance of currency were lifted. There are private firms (banks) owned by the households, that then create and produce non-interest-bearing currency, again called 'wim' for the representative bank. Assume they maximise profits and that there is free entry and exit into the banking sector. In equilibrium the banking sector will therefore make no pure profits, so we don't have to worry about including bank equity in the asset menus and endowments of the households. If euro bonds and media of exchange on which interest can be paid are 
imperfect substitutes for the old euro currency but the new private currency is a perfect substitute for the old euro currency, there will be a demand for the new private currency. The real value of currency demanded would still be given by equation (55).

When writing down the profit function of a bank, we must make an assumption about whether the currency it issues is irredeemable in the sense we assumed government fiat money to be irredeemable. If it is irredeemable, the present discounted value of the terminal stock of private bank currency outstanding can be positive, if not, it must be zero. For private banks I prefer the assumption that the currency they issue must ultimately be redeemed in present discounted value terms. Let $f_{t}$ be the fixed real cost of producing currency in period t. The bank maximizes the present discounted value of current and future real profits:

$$
E_{t} \sum_{j=1}^{\infty} R_{t+j, t}^{*}\left(\frac{\Delta M_{t+j}^{*}}{P_{t+j}}-f_{t+j-1}\right)
$$

I have assumed the marginal cost of issuing currency is zero (a reasonable assumption, as it is always possible, with negligible cost, to add a zero to the face value of a currency note). In that case, there will be an incentive in each period, in a competitive setting where each bank takes the general price level, $P^{*}=S P$, and the stochastic discount factors $R_{t+j, t}^{*}$ as given, to continue issuing currency, that is, to boost $\Delta M^{*}$, as long as currency has any positive value. An infinite price level in each period would be the outcome - there would be no equilibrium

If there were a private monopoly, which allowed for the endogeneity of discount rates and prices, the present discounted value of current and future real seigniorage would, for money demand functions that have the Laffer curve property (see Buiter (2007b)) be maximised (in the stationary case), when the wim risk-free nominal interest rate equals the reciprocal of the (absolute value of the) semi-elasticity of demand for money with respect to 
that interest rate. Since this is surely a positive number, the zero lower bound would never bind in this economy. The budget constraints of the households would have to be modified to include their share of the profits from the monopoly bank.

If the private sector were regulated (neither competitive nor a monopoly), the authorities could restrict the rate of issuance of private wim currency to the point that the zero lower bound in wim interest rates became a binding constraint. In that case, we would, except for the distribution of the profits of the regulated banking sector, be back to the case of the wim currency model with pet rocks.

\section{The liquidity trap and quantitative easing}

The model has implications for the conditions under which a liquidity trap exists in the case where the lower bound constraint is not removed by any of the three methods outlined in Sections 3 and 4. I interpret a liquidity trap as an equilibrium in which risk-free nominal interest rates at all maturities are at their lower bound (typically zero). There are stronger versions of the liquidity trap, which require not only that risk-free nominal interest rates at all maturities be at their lower bound, but also that all liquidity premia at all maturities be zero.

In the model used in this paper, which is a complete markets model with frictionless markets, there are no liquidity premia. Indeed, as the complete markets assumption is combined with the (implicit) assumption that there is costless enforcement of the intertemporal budget constraints of all agents, there also are no default risk premia, as every agent, in every state of nature, always satisfies his intertemporal budget constraint and consequently there is no default risk. 
It is easily shown in the model of this paper that there exists no liquidity trap equilibrium in this economy, unless the authorities demonetise the economy. In this section I return to the euro currency model.

In period $t$, the risk-free nominal discount factor over a $j$-period horizon $j \geq 1 \mathrm{j}$ is defined by

$$
\begin{aligned}
& E_{t} I_{t+j, t}=E_{t} \prod_{k=t+1}^{t+j} I_{k, k-1} \\
& =E_{t}\left(I_{t+1, t} E_{t+1}\left(I_{t+2, t+2} E_{t+2}\left(I_{t+3, t+2}\left(\ldots . E_{t+j-1} I_{t+j, t+j-1}\right) \ldots\right)\right)\right)=\prod_{k=t+1}^{t+j} \frac{1}{1+i_{k, k-1}}
\end{aligned}
$$

In a liquidity trap, therefore, $i_{k+1, k}=i_{k+1, k}^{M}, k \geq t$. Now consider the household solvency constraint (17), which holds with equality, the definition of private financial wealth (9), the asset market equilibrium condition (28) and the government solvency constraint (23). Assume the government solvency constraint holds with equality - this is a policy choice open to the authorities. We then obtain from the household solvency constraint:

$$
\lim _{j \rightarrow \infty} E_{t} I_{j+1, t}\left(\left(1+i_{j+1, j}\right) B_{j}+\left(1+i_{j+1, j}^{M}\right) M_{j}\right)=0
$$

and from the government solvency constraint:

$$
\lim _{j \rightarrow \infty} E_{t} I_{j+1, t}\left(1+i_{j+1, j}\right) B_{j}=0
$$

Equations (75) and (76) imply that,

$$
\lim _{j \rightarrow \infty} E_{t} I_{j+1, t}\left(1+i_{j+1, j}^{M}\right) M_{j}=0
$$

Assume that we are in a liquidity trap equilibrium. It is easily seen that (77) is violated unless the proportional growth rate of the nominal stock of base money is below the interest rate on base money. In a liquidity trap

$$
\lim _{j \rightarrow \infty} \prod_{k=t+1}^{j}\left(\frac{1}{1+i_{k, k-1}^{M}}\right) E_{t} M_{j}=0
$$


This will only be satisfied if the long-run expected proportional growth rate of the monetary base is less that the long-run value of $i^{M}$. Consider the practically relevant case where the nominal interest rate on currency is zero. Equation (78) becomes

$$
\lim _{j \rightarrow \infty} E_{t} M_{j}=0
$$

So a liquidity trap equilibrium exists only if the authorities are expected to demonetise the economy in the long run.

Equation (77) is almost the same as the transversality condition of the household optimum problem given in (15), although it is an implication of solvency constraints rather than an optimality condition.

$$
P_{t} \lim _{j \rightarrow \infty} E_{t}\left(c_{t+j}^{-\gamma} \frac{\beta^{j}}{\Pi_{t+j, t}} M_{t+j}\right)=0
$$

In the fundamental stationary equilibrium of the deterministic flexible price version of the model with constant values of the exogenous variables, summarised in equations (39) to (44), equations (76) and (80) are equivalent, since household consumption is bounded.

Unless the authorities demonetize the economy in the long run (if the interest rate on currency is zero), there can be no liquidity trap equilibrium because the shadow value of the terminal money stock would not go to zero. Households would severally try to get rid of excessive money balances, something that, in the aggregate they cannot do. This can be viewed as a formal version of the 'hot potato' view of money.

Friedman's optimal quantity of money (OQM) equilibrium rule (Friedman (1969)) does indeed have the property that the nominal stock of base money goes to zero asymptotically, even though there is satiation in real money balances in every period (see Buiter and Sibert (2007). 


\section{Conclusion}

This paper discusses three methods for removing the zero lower bound on nominal interest rates. All three are technically feasible, indeed operationally simple. Abolishing currency may seem drastic, but should present no significant logistical problems for advanced economies, except for the underground (grey and black economy). Taxing currency would be the most administratively demanding and intrusive of the three methods. Unbundling the numéraire from the currency would seem to have lack of familiarity as the main argument against it.

Whatever the demerits of these three operational schemes for removing the lower bound on nominal interest rates, they must be set against the economic cost of handicapping the central bank in its pursuit of expansionary monetary policies through the continued existence of the zero floor. If, but for the zero lower bound, the Federal Funds target rate ought indeed to have been set at minus five percent, the cost of not being able to go below zero could be vast indeed. We do not know what scale and scope of unconventional monetary policies, such as quantitative easing or credit easing, can compensate for the asymmetry in the domain over which the official policy rate can range. It may indeed be the case that no amount of quantitative easing or credit easing can make up for the inability of the monetary authorities to set negative nominal interest rates. The subject matter of this paper is therefore not a theoretical curiosum. It is a practical monetary policy issue of great importance. 


\begin{tabular}{|c|c|c|c|c|c|c|c|c|}
\hline \multicolumn{9}{|c|}{$\begin{array}{l}\text { Table 1: Euro notes outstanding } \\
\text { in quantities (millions), outstanding amounts, end of period }\end{array}$} \\
\hline Year & Total & $€ 500$ & $€ 200$ & $€ 100$ & $€ 50$ & $€ 20$ & $€ 10$ & $€ 5$ \\
\hline 2006 & 11,349 & 419 & 153 & 1,116 & 4,078 & 2,337 & 1,901 & 1,346 \\
\hline 2007 & 12,114 & 453 & 156 & 1,209 & 4,442 & 2,468 & 1,965 & 1,421 \\
\hline 2008 & 13,116 & 530 & 170 & 1,381 & 4,912 & 2,618 & 2,030 & 1,476 \\
\hline 2008 Q3 & 11,836 & 473 & 159 & 1,241 & 4,384 & 2,358 & 1,847 & 1,375 \\
\hline 2008 Q4 & 13,116 & 530 & 170 & 1,381 & 4,912 & 2,618 & 2,030 & 1,476 \\
\hline 2009 Q1 & 12,319 & 543 & 171 & 1,369 & 4,635 & 2,383 & 1,833 & 1,385 \\
\hline Feb. & 12,273 & 538 & 170 & 1,363 & 4,597 & 2,380 & 1,837 & 1,388 \\
\hline Mar. & 12,319 & 543 & 171 & 1,369 & 4,635 & 2,383 & 1,833 & 1,385 \\
\hline Apr. & 12,663 & 546 & 171 & 1,382 & 4,755 & 2,478 & 1,913 & 1,418 \\
\hline
\end{tabular}

\begin{tabular}{|c|c|c|c|c|c|c|c|c|}
\hline \multicolumn{9}{|c|}{$\begin{array}{l}\text { Table 2: Euro notes outstanding } \\
\text { in value ( } € \text { billions), outstanding amounts, end of period }\end{array}$} \\
\hline Year & Total & 500 & 200 & 100 & 50 & 20 & 10 & 5 \\
\hline 2006 & 628 & 210 & 31 & 112 & 204 & 47 & 19 & 7 \\
\hline 2007 & 677 & 226 & 31 & 121 & 222 & 49 & 20 & 7 \\
\hline 2008 & 763 & 265 & 34 & 138 & 246 & 52 & 20 & 7 \\
\hline 2008 Q3 & 684 & 236 & 32 & 124 & 219 & 47 & 18 & 7 \\
\hline 2008 Q4 & 763 & 265 & 34 & 138 & 246 & 52 & 20 & 7 \\
\hline 2009 Q1 & 747 & 271 & 34 & 137 & 232 & 48 & 18 & 7 \\
\hline Feb. & 742 & 269 & 34 & 136 & 230 & 48 & 18 & 7 \\
\hline Mar. & 747 & 271 & 34 & 137 & 232 & 48 & 18 & $\begin{array}{ll}7 \\
3\end{array}$ \\
\hline Apr. & 759 & 273 & 34 & 138 & 238 & 50 & 19 & $\begin{array}{ll}97 \\
7\end{array}$ \\
\hline
\end{tabular}




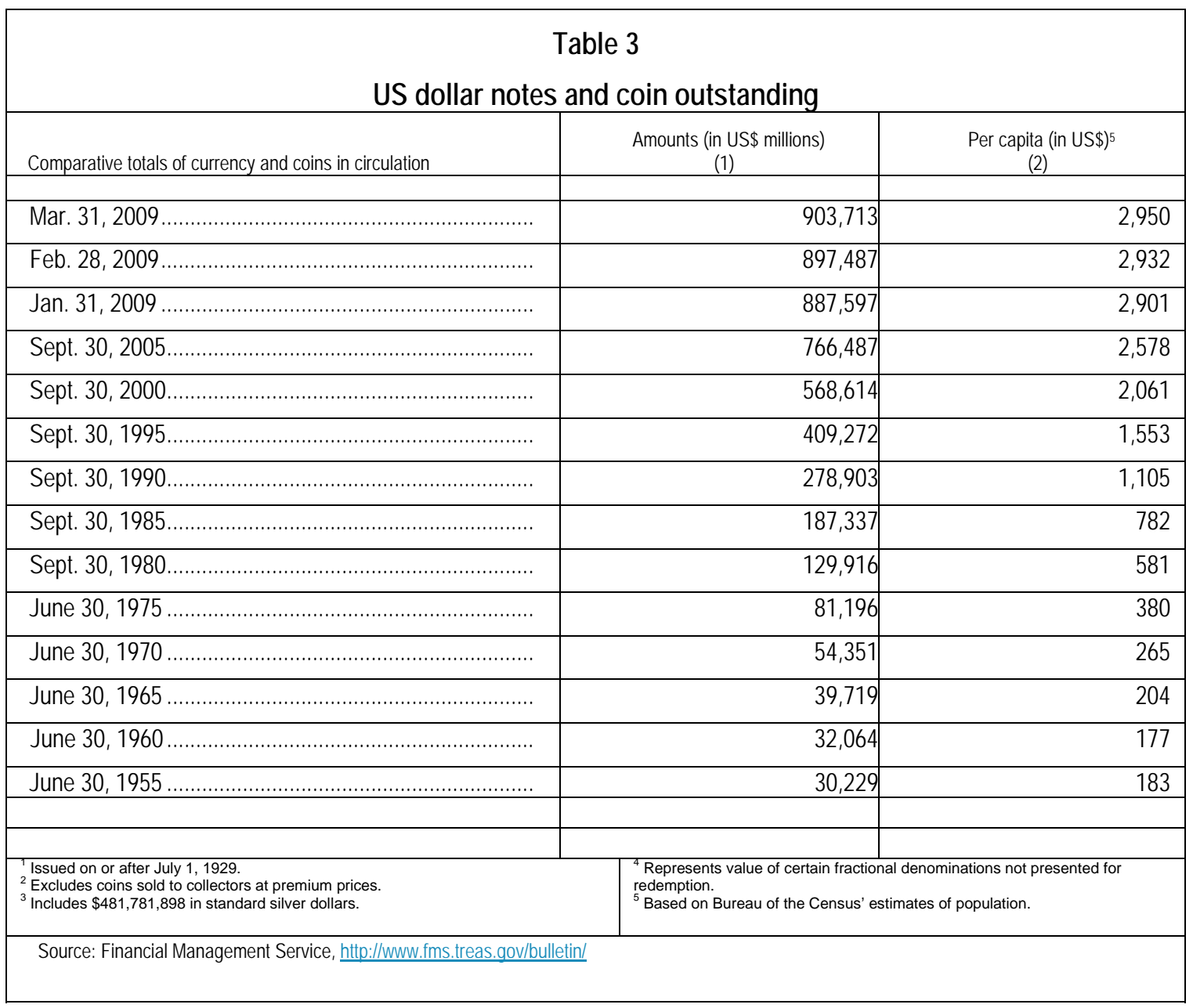

\section{TABLE 4}

\section{Amounts of US\$ notes in circulation by denomination, March 31, 2009, in US\$}

[Source: Financial Management Service]

\begin{tabular}{|c|c|c|c|c|}
\hline Currency in circulation by denomination & $\begin{array}{l}\text { Total } \\
(1)\end{array}$ & $\begin{array}{l}\text { Federal Reserve notes }{ }^{1} \\
(2)\end{array}$ & $\begin{array}{l}\text { U.S. notes } \\
\text { (3) }\end{array}$ & $\begin{array}{c}\text { Currency no } \\
\text { longer issued } \\
(4)\end{array}$ \\
\hline$\$ 1$ & $9,217,168,789$ & $9,074,323,558$ & 143,503 & $142,701,728$ \\
\hline 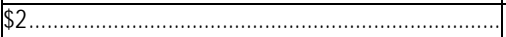 & $1,671,410,074$ & $1,539,287,228$ & $132,110,218$ & 12,628 \\
\hline 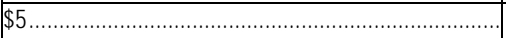 & $10,620,935,820$ & $10,485,371,420$ & $108,759,410$ & $26,804,990$ \\
\hline 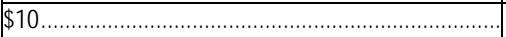 & $15,586,970,720$ & $15,565,997,310$ & 6,300 & $20,967,110$ \\
\hline 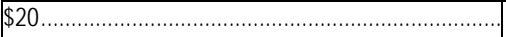 & $120,578,759,840$ & $120,558,649,620$ & 3,840 & $20,106,380$ \\
\hline 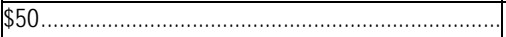 & $63,424,537,400$ & $63,413,032,950$ & 500 & $11,503,950$ \\
\hline 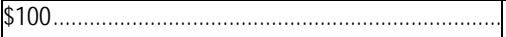 & $642,660,985,700$ & $642,638,781,000$ & 198,000 & $22,006,700$ \\
\hline$\$ 500 .$. & $142,283,000$ & $142,075,000$ & 5,500 & 202,500 \\
\hline 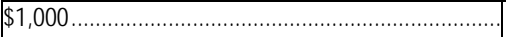 & $165,631,000$ & $165,382,000$ & 5,000 & 244,000 \\
\hline 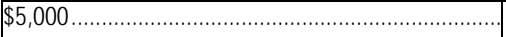 & $1,780,000$ & $1,710,000$ & & 70,000 \\
\hline 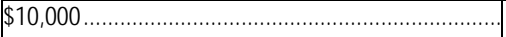 & $3,520,000$ & $3,360,000$ & & 160,000 \\
\hline 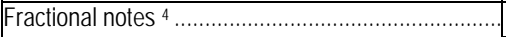 & 600 & & 90 & 510 \\
\hline 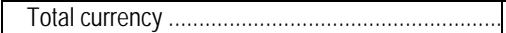 & $864,073,982,943$ & $863,587,970,086$ & $241,232,361$ & $244,780,496$ \\
\hline
\end{tabular}




\section{References}

Bolt, Wilko (2003), "Retail payments in the Netherlands: Some facts and some theory" Research Memorandum WO no. 722, January 2003, De Nederlandsche Bank

Buiter, Willem H. (2003), "Helicopter Money: Irredeemable Fiat Money and the Liquidity Trap", NBER Working Paper No. W10163, December.

Buiter, Willem H. (2004), ,Overcoming the Zero Bound: Gesell vs. Eisler; Discussion of Mitsuhiro Fukao's 'The Effects of 'Gesell' (Currency) Taxes in Promoting Japan's Economic Recovery". International Economics and Economic Policy, Volume 2, Numbers 23, November 2005, pp. 189-200. Publisher: Springer-Verlag GmbH; ISSN: 1612-4804 (Paper) 1612-4812 (Online).

Buiter, Willem H. (2007a), "Is Numérairology the Future of Monetary Economics? Unbundling numéraire and medium of exchange through a virtual currency with a shadow exchange rate", Open Economies Review, Publisher Springer Netherlands; ISSN 0923-7992 (Print); 1573-708X (Online). Electronic publication date: Thursday, May 03, 2007. See "Springer Website".

Buiter, Willem H. (2007b), "Seigniorage ", economics - The Open-Access, Open-Assessment E-Journal, 2007-10.

Buiter, Willem H. (2009a), "Negative interest rates: when are they coming to a central bank near you?", Willem Buiter's Maverecon blog on FT.com, May 7.

Buiter, Willem H. (2009b), "The Wonderful World of Negative Nominal Interest Rates, Again," Willem Buiter's Maverecon blog on FT.com, May 19.

Buiter, Willem H. (2009c), "Negative interest rates, Sharia law and tech stocks", Willem Buiter's Maverecon blog on FT.com, May 20.

Buiter, Willem H. and Nikolaos Panigirtzoglou (2001), "Liquidity Traps: How to Avoid Them and How to Escape Them", in Reflections on Economics and Econometrics, Essays in Honour of Martin Fase, edited by Wim F.V. Vanthoor and Joke Mooij, , pp. 13-58, De Nederlandsche Bank NV, Amsterdam.

Buiter, Willem H. and Nikolaos Panigirtzoglou (2003), "Overcoming the Zero Bound on Nominal Interest Rates with Negative Interest on Currency: Gesell's Solution", Economic Journal, Volume 113, Issue 490, October 2003, pp. 723-746.

Buiter, Willem H. and Anne C. Sibert (2007), "Deflationary Bubbles", Macroeconomic Dynamics, Volume 11, Issue 04, September 2007, pp 431454.http://www.nber.org/ wbuiter/fukao.pdf

Calvo, G. [1983], Staggered Contracts in a Utility-Maximizing Framework, Journal of Monetary Economics, September. 
Davies, Stephen [2004], "Comment on Buiter and Panigirtzoglou”, mimeo, Research Institute for Economics and Business Administration, Kobe University, May.

Einaudi, Luigi [1953], "The Theory of Imaginary Money from Charlemagne to the French Revolution," in F. C. Lane and J. C. Riemersma, eds. Enterprise and Secular Change (George Allen and Unwin, New York, pp. 229 -61.

Einzig, P. (1949), Primitive Money in its Ethnological, Historical and Economic Aspects, Pergamon Press, Oxford. 2nd Ed. 1966.

Eisler, Robert (1932), Stable Money: the remedy for the economic world crisis: a programme of financial reconstruction for the international conference 1933; with a preface by Vincent C. Vickers. London: The Search Publishing Co.

Federal Reserve Bank of Cleveland (2008), "Stamp Scrip: Money People Paid to Use" Economic Commentary, April 2008http://findarticles.com/p/articles/mi qa5294/, by Bruce Champ.

Feige, Edgar L., Michael Faulend, Velimir Šonje and Vedran Šošić (2002), “Currency Substitution, Unofficial Dollarization and Estimates of Foreign Currency Held Abroad: The Case of Croatia", Chapter 7 in Mario Blejer and Marko Skreb (eds), Financial Policies in Emerging Markets, Cambridge, MA: MIT Press.

Financial Times (2009), "Fed study puts ideal interest rate at -5\%", Guha Krishna, April 29.

Fisher, I. (1933), Stamp Scrip, Adelphi Company, New York.

Friedman, M. (1969), .The Optimum Quantity of Money., in Milton Friedman, The Optimum Quantity of Money and Other Essays, Chapter 1, pp.1-50, Adline Publishing Company, Chicago.

Fukao, Mitsuhiro (2005), “The Effects of 'Gesell' (Currency) Taxes in Promoting Japan's Economic Recovery", Tokyo: Institute of Economic Research of the Hitotsubashi University, Discussion Paper Series No.94 / June 2005; http://hi-stat.ier.hit-u.ac.jp/

Gaitskell, H. (1969), Four monetary heretics: Douglas - Social Credit, Soddy - Bank Credit, Gesell - Free Money, Eisler - Stable Money, with an introduction by M G Lloyd Pritchard. Christchurch : Lyn Christie \& Son Ltd.

Gesell, Silvio (1916), Die Natuerliche Wirtschaftsordnung, Rudolf Zitzman Verlag, available in English as The Natural Economic Order, Peter Owen Ltd, London, 1958.

Goodfriend, Marvin (2000), "Overcoming the Zero Bound on Interest Rate Policy", in: Journal of Money, Credit, and Banking, Vol. 32(4)/2000, S. 1007 - 1035.

Hall, Robert E. (1997), "Irving Fisher's Self-Stabilizing Money", American Economic Review, Vol. 87, No. 2, Papers and Proceedings, May, pp. 436-438. 
Hall, Robert E. (2002). "Controlling the Price Level", Contributions to Macroeconomics, Volume 2, Issue 12002 Article 5.

Hall, Robert E (1983). “Optimal Fiduciary Monetary Systems" Journal of Monetary Economics.

Hall, Robert E. and Susan Woodward (2009), "The Fed Needs to Make a Policy Statement" 13 April 2009, http://www.voxeu.org/index.php?q=node/3444, VoxEU.

Hicks, J. R. (1967), "The Two Triads", in J. R. Hicks Critical Essays in Monetary Theory, pp. 1 - 60, Oxford, Oxford University Press.

Mankiw, N. Gregory (2009), "It May Be Time for the Fed to Go Negative", in: New York Times April 18, 2009, http://www.nytimes.com/2009/04/19/business/economy/19view.html?_r=1

Niehans J. (1978), The Theory of Money, Johns Hopkins University Press, Baltimore, Maryland.

Patinkin, Don. (1965), Money, Interest, and Prices. 2nd Ed. New York: Harper and Row, 1965.

Rogoff, Kenneth S. (1998), "Foreign and Underground Demand for Euro Notes: Blessing or Curse?" Economic Policy, Vol. 26 (April), pp. 263-303.

Rogoff, Kenneth S. (2002), "The Suprising Popularity of Paper Currency", Finance and Development, Vol. 39, No. 1, March.

Taylor, John B. (2009a). "Monetary Policy and the Recent Extraordinary Measures Taken by the Federal Reserve," Testimony before the Committee on Financial Services, US House of Representatives, February 26, 2009.

Taylor, John (2009b), "Systemic Risk and the Role of Government", Dinner Keynote Speech Conference on Financial Innovation and Crises, Federal Reserve Bank of Atlanta Jekyll Island, Georgia, May 12, 2009

US Treasury (2006), “The Use and Counterfeiting of United States Currency Abroad, Part 3." The final report to the Congress by the Secretary of the Treasury, in consultation with the Advanced Counterfeit Deterrence Steering Committee, pursuant to Section 807 of PL 104132 , September.

Woodford, M. [2003], Interest and Prices; Foundations of a Theory of Monetary Policy, Princeton University Press, Princeton and Oxford. 